\title{
Skriving i naturfag: En analyse av nettbaserte undervisningsressurser fra to nasjonale sentre
}

\author{
Vibeke Lorentzen, ^ Mari-Ann Igland og Randi Solheim \\ Norges teknisk-naturvitenskapelige universitet
}

\section{Sammendrag}

Denne artikkelen er basert på en studie av et utvalg ressurser om skriving i naturfag, hentet fra nettsidene til Skrivesenteret og Naturfagsenteret. I Lcereplanverket for Kunnskapslaftet inngår skriving som grunnleggende ferdighet i alle fag, som en gjennomgående og tverrfaglig kompetanse. De nasjonale sentrene skal, ifølge sine mandat, støtte skolene i arbeidet med å implementere de grunnleggende ferdighetene. Spørsmålet vi søker svar på i denne artikkelen, er hvordan fagrelevant skriving og skriveopplæring er forstått og formidlet i nettressurser fra de to sentrene. Analysene viser at faginnhold og faglige uttrykk vektlegges på ulike måter, noe som kan knyttes til ulike syn på faglig literacy. Mens Naturfagsenterets skrivedidaktiske ressurser primært presenterer fagovergripende perspektiver på skriving i naturfag, legger Skrivesenteret i større grad vekt på fagspesifikke språktrekk og uttrykksmåter. Disse funnene blir drøftet i lys av literacy-forskning og utdanningspolitiske endringer.

Nøkkelord: Naturfagundervisning; skriveopplcering; fagspesifikk literacy; skriving som grunnleggende ferdighet; utdanningspolitikk; New Literacy Studies

\begin{abstract}
Writing in science education: An analysis of web-based resources from two national centres

This article is based on a study of web-based resources for writing in science education, published by The Norwegian Centre for Science Education and the Norwegian Centre for Writing Education and Research. The Norwegian Curriculum includes writing as a basic skill in all subjects, as a comprehensive and interdisciplinary competence. The national centres should, according to their mandates, support schools in their efforts to implement the statutory basic skills. The question we seek answer to in this article, is how disciplinary writing and writing education is understood and communicated in the two centres' web resources. The analysis shows that subject content and subject discourse are emphasized in different ways. This can be related to different perspectives on academic literacy. While the Norwegian Centre for Science Education's writing resources primarily present generic perspectives on writing, the Writing Centre places greater emphasis on linguistic and textual features of scientific texts. These findings are discussed against a backdrop of literacy research and educational policies.
\end{abstract}

Keywords: Science education; writing instruction; disciplinary literacy; writing as a key competence; educational policies; New Literacy Studies

^Korrespondanse:Vibeke Lorentzen, e-post: vibeke.lorentzen@ntnu.no

(C) 2020 Vibeke Lorentzen, Mari-Ann Igland og Randi Solheim. This is an Open Access article distributed under the terms of the Creative Commons Attribution 4.0 International License (https://creativecommons.org/licenses/by$\mathrm{nc} / 4.0 /$ ), allowing third parties to copy and redistribute the material in any medium or format and to remix, transform, and build upon the material for any purpose, even commercially, provided the original work is properly cited and states its license.

Citation:V. Lorentzen, M.-A. Igland $\mathcal{E}$ R. Solheim. "Skriving i naturfag: En analyse av nettbaserte undervisningsressurser fra to nasjonale sentre" Nordic fournal of Literacy Research, Vol. 6(2), 2020, 39-69. http://dx.doi.org/10.23865/njlr.v6.2072 
Ansvarlig redaktør: Per Henning Uppstad

Mottatt: Desember, 2019; Antatt: September 2020; Publisert: Desember, 2020

\section{Bakgrunn}

I den reviderte læreplanen som gjelder fra 2020, videreføres skriving, lesing og muntlighet som tre av fem grunnleggende ferdigheter. Disse ble innført med Kunnskapsløftet høsten 2006 og innebar et historisk «gjennomslag for at fagenes grunnleggende mål er at elevene settes i stand til å utøve fagrelevant skriving, lesing og muntlighet» (Berge, 2005, s. 163). I årene som fulgte ga reformen derfor støtet til økt oppmerksomhet og forskning om nettopp literacy i opplæringa, med særlig vekt på lesing og skriving i og på tvers av alle skolefag (se f.eks. Flyum \& Hertzberg, 2011; Lorentzen \& Smidt, 2008; Skjelbred \& Veum, 2013; Skaftun et al., 2014; Smidt, 2011; Rødnes \& Gilje, 2018). ${ }^{1}$

Denne artikkelen dreier seg om skriving som grunnleggende ferdighet i naturfag. A kunne skrive i dette faget innebærer ifølge Kunnskapsløftets læreplaner (LK06/ LK20) blant annet å formulere spørsmål og hypoteser, å skrive naturfaglige forklaringer basert på evidens og kilder, å beskrive observasjoner og erfaringer og å formulere og argumentere for egne standpunkt. Gjennom skoleløpet skal elevenes skriveferdighet utvikles fra enkle uttrykksformer til presist naturfaglig språk og kritisk og variert kildebruk i stadig mer komplekse tekster i ulike sjangre. På den ene sida vektlegger læreplanen altså ei skriveopplæring som dreier seg om at elevene skal lære å bruke fagets skrivemåter og fagspesifikke uttrykk. På den andre sida løftes skriving fram som verktøy for å forstå og tilegne seg faget. Her ser vi spor av to sentrale retninger når det gjelder skriving i utdanningskontekster - både å skrive for å lære, og å lære å skrive i faget, noe vi kommer tilbake til nedenfor.

I Norge er skriving i grunnskolens naturfag studert i ulike sammenhenger - i klasserom, i skriveoppgaver, elevtekster og lærebøker. Flere klasseromsundersøkelser indikerer at fagskriving som inngår i lengre utforskende arbeidsprosesser med fokus på teksters innhold, form og formål, øker elevenes muligheter for å sette seg inn i naturvitenskapelige temaer og tilegne seg en naturfaglig måte å kommunisere om naturen og verden på (Knain, 2005b; Lykknes \& Smidt, 2008; Torvatn, 2008). Denne typen eksplisitt tekstarbeid fant imidlertid forskerne lite av i naturfagsklasserommene de besøkte i løpet av et prosjekt om lesing av fagtekster som grunnleggende ferdighet i fagene (Skjelbred \& Aamotsbakken, 2010). Lærerne brukte her mye tid på å motivere elevene og gi innføring $\mathrm{i}$ tema det ble arbeidet med, men $\mathrm{i}$ arbeid med skriving og oppgaveløsing ble elevene mye overlatt til seg selv og lærebøkene. Forskerne fant også at lærebøkene i naturfag er preget av informasjonstette tekster med mange krevende

\footnotetext{
${ }^{1}$ Selv om muntlige ferdigheter fikk større plass i L97 og LK06 enn i tidligere planer, har forskning på muntlighet fått mindre oppmerksomhet enn for eksempel lesing og skriving (se f.eks. Rødnes \& Gilje, 2018).
} 
fagtermer, ikke-faglige abstrakte ord og nominaliseringer (Maagerø \& Skjelbred, 2010). Et annet trekk ved naturfaglige lærebøker er at de ofte presenterer etablerte fakta og produkt av vitenskap framfor vitenskapelige prosesser. Dette står i et motsetningsforhold til naturvitenskapelige tekster utenfor skolekonteksten, som gjerne formidler nytt innhold (Sørvik et al., 2015). Skriveaktivitetene som bøkene legger opp til, er i så måte interessante. I studier av lærebøker i naturfag for 8. trinn fant Lykknes og Arnesen (2008) at de fleste skriveoppgavene, med unntak av forsøksrapporter og noen få drøftingsoppgaver, kan kategoriseres som uformelle oppgaver med få krav til form og sjanger. Dette kan synes paradoksalt, tatt i betraktning at naturvitenskapelig kunnskap gjerne formidles gjennom tekster med høy grad av teknikalitet (Maagerø \& Skjelbred, 2010). Studier av skriveoppgaver fra det såkalte Normprosjektet viser at elever skriver mye i skolens naturfag. Samtidig etterlyser forskerne flere oppgaver som kan bidra til at elevene ikke bare skriver for å lære naturfag, men at de lærer å skrive naturfaglig (Lykknes, 2015; Matre et al., 2021). Dette forutsetter at elevene må lære å tolke og reflektere over fagets tekster for selv å kunne produsere slike som en del av fagopplæringa. Kjennskap til fagets sjangre og spesifikke måter å kommunisere faget på er derfor viktig for å giøre en naturvitenskapelig tekstkultur tilgjengelig for elevene (Knain, 2005a).

Målet med denne artikkelen er å gi ny innsikt i hvordan fagrelevant skriving og skriveopplæring i naturfag er forstått og formidlet, gjennom en studie av digitale undervisningsressurser utvikla av Nasjonalt senter for naturfag i opplæringa og Nasjonalt senter for skriveopplæring og skriveforsking. Slike ressurser er ikke viet den samme forskningsmessige oppmerksomheten som lærebøkene ${ }^{2}-$ selv om nasjonale sentre helt siden innføringa av Kunnskapsløftet har hatt ansvar for å utvikle ressurser til støtte for implementeringa av de grunnleggende ferdighetene. Ressursene er fritt tilgjengelige på Utdanningsdirektoratets og de enkelte sentrenes nettsider, ${ }^{3}$ de når ut til et stort publikum og anses som autoritative kilder til kunnskap. Brukerne uttrykker jevnt over tilfredshet med sentrenes leveranser (Gjerustad et al., 2017), og Utdanningsdirektoratet omtaler dem som «eksempler på god praksis» (Utdanningsdirektoratet, 2017).

Med instrukser for undervisningsinnhold så vel som -form representerer sentrenes nettressurser en praksisorientert fortolkning og formidling av norsk utdanningspolitikk. ${ }^{4}$ I så måte er både sentre med et fagovergripende mandat og sentre med

\footnotetext{
${ }^{2}$ Et ferskt unntak er en studie av hvordan to lærere tar i bruk en pedagogisk nettressurs utvikla av Skrivesenteret (Kvithyld, 2019).

${ }^{3}$ De nasjonale sentrene ble overført til sine respektive vertsinstitusjoner i januar 2018. Inntil da hadde Utdanningsdirektoratet hatt ansvaret for den løpende styringa gjennom ordinære rapporteringsrutiner, styringsdialoger og kontaktmøter med senterlederne. Denne situasjonen endret seg etter at styringa ble underlagt vertsinstitusjonene, men ressursene ligger fremdeles på Utdanningsdirektoratets nettsider (per oktober 2019).

${ }^{4} \mathrm{Da}$ sentrene var underlagt Utdanningsdirektoratet, mottok de oppdragsbrev med føringer for sentrenes oppgaver.
} 
ansvar for et bestemt fag viktige bidragsytere til operasjonaliseringa av norsk utdanningspolitikk på flere felt, også på literacy-feltet. Med oppdragene de ivaretar, følger det makt, for eksempel til å definere hva skriving som grunnleggende ferdighet er, eller kan være, og hva som anses som gode skriveopplæringspraksiser. Nettopp derfor er det viktig å vie senterressursene faglig og skrivedidaktisk oppmerksomhet.

Spørsmålet vi stiller i denne artikkelen, er hvordan fagrelevant skriving og skriveopplæring er forstått og formidlet i nettressurser som to sentre med ulik spisskompetanse har utvikla for skriving i naturfag på ungdomstrinnet og publisert på sine respektive hjemmesider. Ressursene er utvikla av Nasjonalt senter for naturfag $i$ opplæringa og Nasjonalt senter for skriveopplæring og skriveforskning. Natufagsenteret har ansvar for et bestemt skolefag med alle de områdene og ferdighetene som faget omfatter - skriving inkludert, mens Skrivesenteret har skriving i og på tvers av alle skolefag som sitt ansvarsområde. Vi har analysert alle nettressursene om skriving i naturfag som disse to sentrene hadde utvikla for ungdomstrinnet og publisert på sine respektive nettsteder per mars 2019. ${ }^{5}$ Det har vi gjort med en teoretisk innfallsvinkel som kombinerer en literacy-orientert forståelse av skriving i og på tvers av fag med et diskursorientert grunnlag for analyse av skriveopplæringspraksiser. Valget av sentre skulle kanskje tilsi et gitt analyseresultat, altså at Skrivesenteret formidler en fagovergripende tilnærming til skriving i naturfag, mens Naturfagsenteret formidler en mer fagspesifikk tilnærming. Analysene motsier en såpass enkel hypotese. Som vi skal se, er sentrenes formidlede forståelser av skriving som grunnleggende ferdighet $\mathrm{i}$ naturfag dels motstridende, dels overlappende og dels i konflikt med det man kunne anta. Hva dette skyldes, og hva det kan innebære, diskuterer vi avslutningsvis.

\section{Teoretiske perspektiver: skriving i og på tvers av fag}

I skolen eksisterer ulike skriveopplæringspraksiser alltid side om side. Noen er mer framtredende enn andre, og dominerende oppfatninger og tilnærminger endrer seg over tid. Når det gjelder arbeidet med skriving som grunnleggende ferdighet, kan slike forskjeller belyses ved hjelp av to ulike tankesett, som både står i motsetning til og griper inn i hverandre. På den ene sida kan vi snakke om fagovergripende perspektiver, der skriving ses som en ferdighet elever og lærere skal arbeide med på tvers av fag. På den andre sida finner vi spesifikke forestillinger om faglighet som løftes fram gjennom beskrivelser av hva slags språk og tekster som verdsettes i de enkelte fagene.

Begge disse retningene kan relateres til tenkninga rundt to skriveopplæringsprogram som ble utvikla ved amerikanske universiteter på 1970-tallet. Den sentrale ideen bak det første av dem, Writing across the curriculum (WAC), var å praktisere skriving som en vei til læring på tvers av fagtradisjoner (Russell, 2002). I norsk sammenheng ble denne ideen tidlig et viktig anliggende for den prosessorienterte skrivepedagogikken,

\footnotetext{
${ }^{5}$ Hos Naturfagsenteret gjelder det ressursene som ligger på temasiden «Grunnleggende ferdigheter». Se utvalgskriterier under omtalen av data og analytisk tilnærming.
} 
som begynte som en grasrotbevegelse på 1980-tallet, og som fra slutten av 1990-tallet ble en del av offentlig skriveopplæringspolitikk (Roe \& Helstad, 2014). A skrive for å lære er fortsatt vektlagt, i amerikansk så vel som norsk skrivepedagogikk, men i forlengelsen av WAC-programmene begynte man å rette større oppmerksomhet mot Writing in the disciplines (WID), altså mot skriving $i$ fagene. Den bærende ideen her var at ulike fag har sine egne sjangre og skrivemåter. En skriveopplæring som fokuserer på fagovergripende strategier, er derfor utilstrekkelig; skriveopplæringa må (også) være fagspesifikk. Selv om WAC og WID gjerne blir sett som motsetninger, er det viktig å være oppmerksom på at de to retningene sammen har bidratt til å øke bevisstheten om skrivekompetanse i og på tvers av fag - både i akademia og i grunnskolen. Læringsperspektivet som WAC bygger på, kan nemlig både inkluderes, videreføres og spisses i ulike fag. En vid forståelse av WID inkluderer dermed både faglig læring, sosialisering og danning (Carter et al., 2007). Slik ses også utvikling av skrivekompetanse i en mer helhetlig sammenheng; man kan både snakke om å skrive for å lære i et overordna perspektiv, og å lære å skrive i fagene.

Timothy og Cynthia Shanahan $(2008,2012)$ omtaler to ulike tilnærminger til literacy som kaster lys over samspill og motsetninger mellom ideene bak skriving $\mathrm{i}$ og på tvers av fag: Content Area Literacy (CAL) og Disciplinary literacy (DL), som framhever henholdsvis fagovergripende og fagspesifikke språk- og tekstkompetanser. Uten å sette ferdighet og danning opp mot hverandre, kan vi si at skriveopplæringas ferdighetsdimension er mest framtredende i CAL-tradisjonens vektlegging av generelle lærings-, lese- og skrivestrategier som kan benyttes uavhengig av fag, mens skriveopplæringas faglige danningsdimensjon kommer tydeligere til uttrykk i DL-tradisjonens vekt på at kunnskap utvikles og uttrykkes på forskjellige måter avhengig av fagenes egenart. Bruk av nominaliseringer er for eksempel relevant i naturfag fordi prosesser og fenomener, ikke personer, utgjør forgrunnen i fagets tekster. I morsmålsfaget, derimot, er personer som ytrer seg eller handler oftere i fokus, og personlige pronomen og aktive verb er derfor mer framtredende (Maagerø \& Skjelbred, 2010; Shanahan \& Shanahan, 2012).

I et CAL-perspektiv er et mål med opplæringa å utvikle elevenes evne til effektivt å bruke lesing og skriving som generiske verktøy for læring i ulike fag. Her fokuseres det gjerne eksplisitt på strategier som de kan bruke i møte med tekster fra ulike skolefag, som for eksempel å skrive sammendrag, ta notater og lage tankekart (Bean et al., 2011; Fang \& Coatoam, 2013; Hoem et al., 2015). I et DL-perspektiv er målet i større grad at elevene skal bli i stand til å engasjere seg i fagrelevante praksiser, både sosialt og kognitivt, gjennom språklige og tekstlige uttrykk (Fang, 2012, s.19). Slik posisjoneres lærerne i større grad som fageksperter som skal veilede elevene inn i et fags tekster og uttrykksmåter. I naturfag innebærer dette blant annet å gjøre elevene kjent med abstrakte idéer, begreper og sjangre som kan ligge langt fra hverdagen deres. Naturfaglige rapporter, forklaringer og utredninger baserer seg gjerne på et fortettet og spesialisert språk, komplekse representasjoner og flere modaliteter. I tillegg til kunnskap om fakta og vitenskapelige begreper handler naturvitenskapelig 


\section{Lorentzen, M. -A. Igland og R. Solheim}

literacy derfor også om evnen til å kunne kombinere ulike semiotiske ressurser for å produsere, organisere og formidle kunnskap (Lemke, 2004). Moje (2010) framhever at det er krevende å innlemme elever i fagenes diskurser, men at dette samtidig er en forutsetning for å utdanne elever som både kan forstå og ta kritisk stilling til fagstoffet. Her er det nærliggende å trekke linjer til oppøving av kritisk literacy, som er sentralt i det norske læreplanverket (se f.eks. Blikstad-Balas, 2016; Veum \& Skovholt, 2020). Kjennskap til fagets uttrykksmåter gjør det også lettere for elevene å forholde seg kritisk spørrende og vurderende til ulike framstillinger av virkeligheten. Å lære å ta $\mathrm{i}$ bruk og forholde seg til slike ressurser på formålstjenlige måter i faglig kommunikasjon er slik et steg på veien mot faglig danning.

I norsk skole kan vi se en utvikling fra vekt på fagovergripende perspektiver på literacy etter innføringa av grunnleggende ferdigheter med LK06, til økt bevissthet om behovet for fagspesifikke språk- og tekstkompetanser ved revisjonen i 2013 (Møller et al., 2010; Smidt, 2011) og i prosessen fram mot fagfornyelsen i 2020 (NOU 2014: 7; NOU 2015: 8; Meld. St. 28(2015-2016)). Denne utviklingslinja giør seg gjeldende i ulike fag, og både innen lesing og skriving.

I denne artikkelen fokuserer vi på fagovergripende og fagspesifikke skriveopplæringspraksiser, slik de formidles diskursivt gjennom nettressurser som skal støtte implementeringa av skriving som grunnleggende ferdighet. Vi anvender altså praksisbegrepet som en teoretisk-diskursiv optikk, og forståelsen av dette begrepet forankrer vi $\mathrm{i}$ teorier både fra diskursanalyse og new literacy studies (NLS).

I Faircloughs versjon av kritisk diskursanalyse er sosiale praksiser forstått som medierende enheter mellom abstrakte sosiale strukturer og konkrete sosiale hendelser. Strukturene definerer et sett av muligheter knytta til samfunnsmessige og institusjonelle makroforhold, som økonomiske og politiske føringer, maktforhold og byråkrati. Hendelsene er situerte og konstituerer det som faktisk er eller blir realisert, og det mellomliggende, medierende leddet artikulerer sosial praksis «in its language aspect» (Fairclough, 2003, s. 21), altså som diskurs, sammen med andre ikke-diskursive sosiale elementer.

Innenfor NLS er literacy-praksiser og literacy-hendelser sentrale begreper med noe snevrere betydning. De ble introdusert hver for seg av Brian Street (1984) og Shirley Brice Heath (1983), og deretter etablert som et grunnleggende begrepspar, ikke minst gjennom David Barton (1994) som var den første til å sammenfatte det nye literacy-feltet. Barton (2007) har senere utdypet de to begrepene og relasjonene mellom dem. Kort forklart står literacy-praksiser for abstrakte, kulturelt betinga mønstre for handling som bærer med seg verdier, holdninger og tankesett fra mer omfattende sosiokulturelle strukturer som de inngår i. Literacy-hendelser står derimot for konkrete, observerbare realiseringer av muligheter som slike praksiser byr på. Hendelsene gir oss dermed indirekte tilgang til praksisene de drar veksler på, og nettopp derfor er de det primære studieobjektet i nyere literacy-studier.

Nyere literacy-forskning legger altså et teoretisk grunnlag for å avlede literacypraksiser fra studier av konkrete hendelser, mens Fairclough (2003) legger et grunnlag 
for å studere sosiale praksiser diskursivt, altså slik de er nedfelt og formidlet i skrift og tale. Det vi belyser i denne studien, er diskursivt formidla forståelser av skriving og skriveopplæringspraksiser som står, eller søker å stå, i et medierende forhold til offentlig utdanningspolitikk på den ene sida og klasseromspraksis på den andre.

\section{Data og analytisk tilnærming}

Både Naturfagsenteret og Skrivesenteret har omfattende nettsteder som tilbyr en lang rekke ressurser for ulike trinn i utdanningsløpet, fra barnehage til høyere utdanning. De lenker også til hverandres sider. Som illustrert nedenfor (figur 1), består sentrenes nettressurser av multimodale tekster med verbaltekst og bilder. Filmer og videopresentasjoner er også mye brukt. Alle ressursene har klikkbare lenker, både i og ved sida av hovedteksten, som regel til relaterte ressurser på senterets sider, men også til andre tekster innenfor eller utenfor nettstedet. Begge sentrene gir dermed tilgang til en tilsynelatende ubegrenset mengde tekster som er potensielt relevante for å belyse artikkelens forskningsspørsmål.

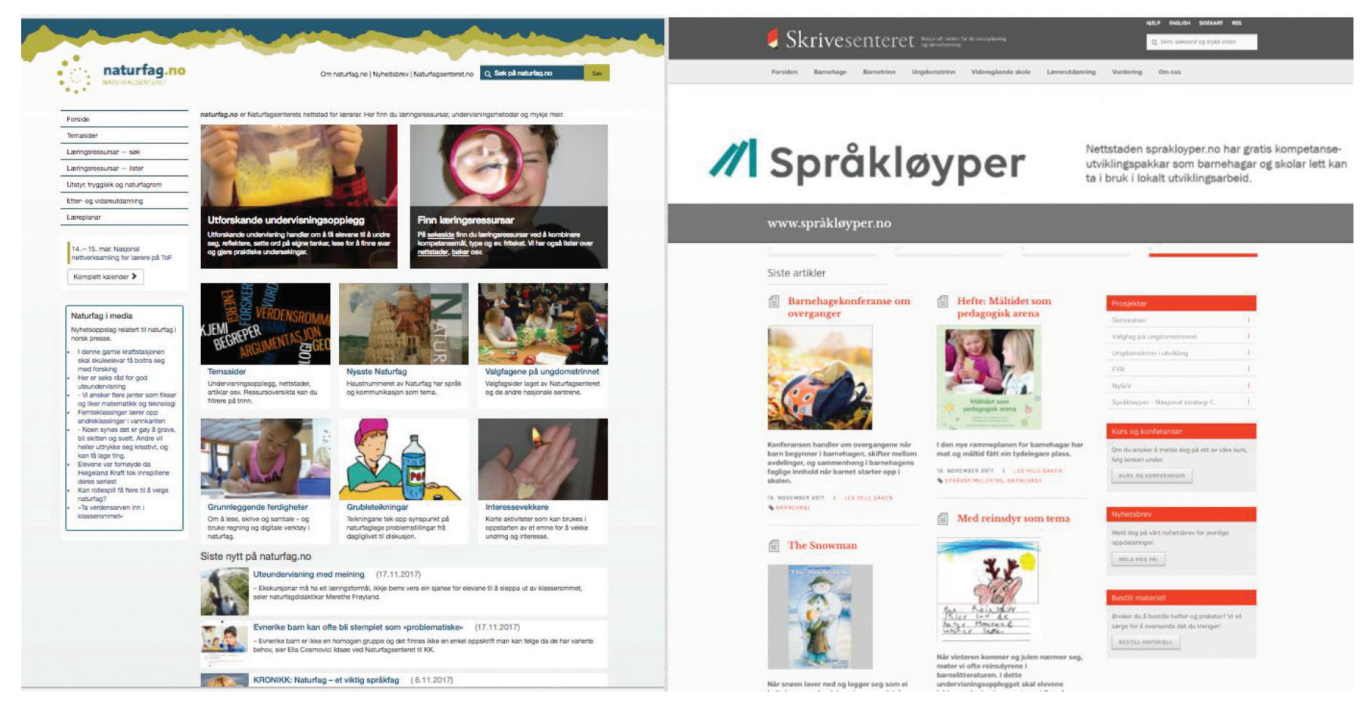

Figur 1. Skjermbilder fra nettsidene naturfag.no og skrivesenteret.no

Som nevnt innledningsvis, har vi analysert alle aktuelle ressurser om skriving i naturfag på ungdomstrinnet som er publisert på Skrivesenterets og Naturfagsenterets nettsider per mars 2019. Ettersom målet er å undersøke sentrenes egen fagformidling, er eksterne ressurser som sentersidene lenker til, utelatt. Tekstutvalget vi da har endt opp med, omfatter til sammen 19 nettstedinterne ressurser om skriving i naturfag. På Naturfagsenterets nettsted (naturfag.no) fant vi alle de aktuelle ressursene på temasider «Grunnleggende ferdigheter». Ved å filtrere søket til å gjelde ressurser som tematiserer skriving for ungdomstrinnet, fikk vi opp 31 ressurser fra en sentralt plassert 


\section{Lorentzen, M. - A. Igland og R. Solheim}

oversikt med til sammen 50 ressurser. De 14 nettressursene som inngår i vårt utvalg, tematiserer skriving og er merket «8-10» (se oversikt i figur 2 under). En av disse er en samleressurs som består av 11 artikler om argumentasjon, hvorav fire av artiklene omhandler skriving (I, J, K, L) og dermed inngår i vårt ressursutvalg. På nettstedet til Skrivesenteret (skrivesenteret.no) er alle de aktuelle ressursene sortert under fanen «Realfag» på sider rettet mot ungdomstrinnet. Klikker man på fanen «Se alle ressurser», kommer det fram åtte ressurser som tematiserer skriving i matematikk, naturfag eller begge deler. Fem av disse interne ressursene er merket med naturfag og inngår derfor i vårt utvalg (se figur 2).

I oversikten nedenfor er hver ressurs merket med en bokstav $(A-S)$ for å lette henvisningen til ressursene senere $\mathrm{i}$ artikkelen. De fire første ressursene $(\mathrm{A}-\mathrm{D})$, to fra hvert senter, er markert med blått. Disse tekstene utgjorde et eget utvalg som ble analysert i en forstudie (se nedenfor). Det samla utvalget består av mange flere ressurser fra Naturfagsenteret enn Skrivesenteret. Dette skyldes forskjeller på sentrenes sider: Skrivesenteret skiller ut ressurser som er rettet mot bestemte trinn, mens flere av Naturfagsenterets ressurser retter seg både mot barnetrinn, ungdomstrinn og videregående. Dessuten inkluderer Naturfagsenter-ressursene gjerne flere ferdigheter, mens alle Skrivesenter-ressursene naturlig nok har skriving som sitt hovedanliggende. Selv om skriving er med i alle ressursene vi analyserer, er det altså ikke slik at denne grunnleggende ferdigheten er i forgrunnen i alle utvalgsressursene fra Naturfagsenteret.

For å få innsikt i empirien - og grunnlag for å velge relevante analytiske innganger gjorde vi innledningsvis en studie av et utvalg aktuelle ressurser. Valget av tekster til denne forstudien ble forankra i tiltenkte brukeres kunnskap og skjønn. Slik kunne vi sikre at vi analyserte tekster som lærerne faktisk ville bruke. 10 erfarne grunnskolelærere med ulik grad av naturfaglig fordypning og erfaring, fra sju ulike skoler, ble hver for seg spurt om hvilke to nettressurser fra hvert senter de ville valgt å lese først dersom de søkte informasjon om skriving som grunnleggende ferdighet i naturfag. Alle valgte de samme ressursene fra Naturfagsenterets nettsider (A og B). Én av ressursene fra Skrivesenteret ble også valgt av alle (C), mens den andre (D) ble valgt av ni. ${ }^{6}$ At lærerne var så samstemte i sine valg, hang trolig sammen med at tekstene de festet seg ved, er løftet fram som introduksjonstekster om grunnleggende ferdigheter i naturfag på hvert av sentrenes nettsteder. Det er derfor rimelig å anta at ressursene anses å gi en første oversikt over emnet og er prioritert av sentrene. Med en samlebetegnelse omtaler vi dem videre som inngangstekster. Både inngangstekstene og resten av ressursutvalget blir nærmere presentert i analysedelen (se figur 3, 4 og 6).

\footnotetext{
${ }^{6}$ Læreren som giorde et avvikende valg, landet på en femte ressurs, ressurs Q (se figur 2). Dette henger trolig sammen med at hun gikk veien om et Google-søk for å finne ressursene, mens de andre lærerne gikk rett til sentrenes respektive hjemmesider.
} 


\begin{tabular}{|c|c|c|c|}
\hline \multicolumn{2}{|r|}{ Ressurser fra naturfag.no } & \multicolumn{2}{|r|}{ Ressurser fra skrivesenteret.no } \\
\hline A & $\begin{array}{l}\text { Naturfag, læringsstrategier og grunnleggende } \\
\text { ferdigheter (Nergård, 2006) }\end{array}$ & $\mathrm{C}$ & Skriving i realfag (2014) \\
\hline $\mathrm{B}$ & $\begin{array}{l}\text { Lese, skrive og samtale om } \\
\text { naturvitenskapelige emner (Kolstø, 2006) }\end{array}$ & D & Skriving i naturfag (2012) \\
\hline $\mathrm{E}$ & Lag en brosjyre (Mork \& Erlien, 2010) & Q & Rapportskriving i naturfag (2012) \\
\hline $\mathrm{F}$ & $\begin{array}{l}\text { Lag en plakat om en utforsking av } \\
\text { verdensrommet (Kvande \& Sørborg, u.å.) }\end{array}$ & $\mathrm{R}$ & $\begin{array}{l}\text { Elevens naturfagrapport som eksempeltekst } \\
(2012)\end{array}$ \\
\hline G & $\begin{array}{l}\text { Å lage et sammendrag (Folkvord \& Mahan, } \\
\text { 2006) }\end{array}$ & $\mathrm{S}$ & $\begin{array}{l}\text { Skriving knyttet til praktisk arbeid (Knain, } \\
\text { 2015) }\end{array}$ \\
\hline $\mathrm{H}$ & $\begin{array}{l}\text { Engasjerende utgangspunkt for skriving } \\
\text { (Mork, 2015) }\end{array}$ & & \\
\hline I & $\begin{array}{l}\text { Hvorfor argumentasjon i naturfag? (Mork, } \\
\text { 2009) }\end{array}$ & & \\
\hline $\mathrm{J}$ & $\begin{array}{l}\text { Hvordan tilrettelegge for argumentasjon i } \\
\text { undervisningen? (Mork, 2009) }\end{array}$ & & \\
\hline $\mathrm{K}$ & $\begin{array}{l}\text { Skriving av eksperimentrapporter som } \\
\text { opplæring i argumentering (Kolstø, 2009) }\end{array}$ & & \\
\hline $\mathrm{L}$ & $\begin{array}{l}\text { Gi din stemme for naturfaget i skolen - en } \\
\text { retorisk hyllest til naturfaglig opplysning } \\
\text { (Flyum, 2010) }\end{array}$ & & \\
\hline M & $\begin{array}{l}\text { «Du vet ikke hva du har skjønt før du har satt } \\
\text { ord på det!» (Hertzberg, 2006) }\end{array}$ & & \\
\hline $\mathrm{N}$ & $\begin{array}{l}\text { Grunnleggende ferdigheter i teknologi og } \\
\text { design (Bach, u.å.) }\end{array}$ & & \\
\hline $\mathrm{O}$ & $\begin{array}{l}\text { Bruk av BISON-blikk på naturfaglige tekster } \\
\text { (Braute \& Dahl, u.å.) }\end{array}$ & & \\
\hline $\mathrm{P}$ & Digitalt tankekart (Hoff, 2009) & & \\
\hline
\end{tabular}

Figur 2. Utvalget av ressurser fra naturfag.no og skrivesenteret.no som inngår i våre analyser

I første omgang ble de fire inngangstekstene analysert med fokus på språklige, tekstlige og diskursive hovedtrekk som kunne bære bud om forståelsen av fagrelevant skriving og hva slags skriveopplæringspraksiser ressursene vektlegger og eventuelt anbefaler (se vedlegg 1). Til dette formålet brukte vi redskaper fra Faircloughs 


\section{Lorentzen, M. - A. Igland og R. Solheim}

tekstbaserte diskursanalyse $(2003,2015)$. Hans omfattende analytiske rammeverk er organisert rundt et sett med spørsmål som må tilpasses den enkelte studiens fokus (Fairclough, 2015, s. 129). Her la vi vekt på språkbruk (ordvalg og -frekvens), sjanger og sjangerblanding, tekstens forpliktelser (representasjon av sosiale hendelser, her agens og metaforer; stil; modalitet), fortolkninger (ordsammenstillinger og antakelser) og forankringer (intertekstualitet, her kilder, referanser og sitater; diskurser og interdiskursivitet). Analysen av disse tekstene (se nedenfor, samt vedlegg) viser også hvordan kategorier som er problemdrevet, kombineres med innganger som er teoridrevet (se ovenfor). I neste omgang ble kategoriene som utkrystalliserte seg i denne prosessen, videreutviklet med støtte i ny empiri. Her ble hele ressursutvalget nærlest og analysert med bakgrunn i funnene fra analysen av inngangstekstene. Ettersom forstudien dannet et viktig grunnlag for utviklinga av analyseverktøy, presenteres kategoriene og videreutviklinga av disse i innledninga til hovedstudiens analyser.

Førsteforfatteren har hatt hovedansvaret for forskningsprosessen og analyserte i første omgang hele ressursutvalget på egen hånd. Som grunnlag for sammenligning og kvalitetssikring gjorde medforfatterne i tillegg individuelle analyser av ressursene. Dernest ble det gjort kollektive analyser i flere omganger med vekt på diskusjon av erfaringer og funn underveis og kontinuerlig raffinering av analyseverktøy. Utviklinga av kategorier i lys av teoriene vi la til grunn, var sentralt i disse prosessene. ${ }^{7}$

\section{Analyse av inngangstekstene}

Alle de fire inngangstekstene har titler som kan sies å bære bud om innføring og oversikt. I figuren nedenfor (figur 3) beskrives de som henholdsvis bakgrunnstekster om grunnleggende ferdigheter (A og B) og introduksjonstekster om skriving i naturfag (C og D). Tekstene fra Naturfagsenteret er fra 2006, men de har beholdt sin framskutte posisjon på senterets temaside om grunnleggende ferdigheter. De to Skrivesenterressursene er publisert seks og åtte år seinere, altså i 2012 og 2014. Siden utdanningspolitiske føringer for skriving som grunnleggende ferdighet har endret seg noe over tid, kan denne tidsforskjellen ha vært av betydning (se drøftingsdelen).

Som figuren viser, er Naturfagsenterets ressurser tre og fire ganger så lange som Skrivesenterets (målt i løpende ord). Begge er i all hovedsak bygd opp på tilsvarende vis som papirbaserte fagartikler og illustrert med bilder av elever. Den ene teksten fra Skrivesenteret har ingen bilder (C), den andre har en skjermdump med bilde av en naturfaglig rapport fra en videofilm (D). Her er det altså ikke elever, men resultatet av en skriveprosess som er avbildet. I tillegg er filmen i sin helhet integrert i nettressursen via en tekstintern lenke.

I analysene av inngangstekstene (se også vedlegg 1) finner vi at Naturfagsenterets tekst $\mathrm{A}$ anbefaler en skriveopplæringspraksis som baserer seg på eksplisitte koplinger

${ }^{7}$ Dette har ikke minst vært viktig fordi førsteforfatteren er ansatt ved Skrivesenteret. 


\begin{tabular}{|c|c|c|c|c|}
\hline \multicolumn{3}{|c|}{ Naturfag.no } & \multicolumn{2}{|c|}{ Skrivesenteret.no } \\
\hline $\begin{array}{l}\text { Tittel og } \\
\text { publ.år }\end{array}$ & $\begin{array}{l}\text { A: Naturfag, } \\
\text { laringsstrategier og } \\
\text { grunnl eggende } \\
\text { ferdigheter } \\
\text { (Nergård, 2006) }\end{array}$ & $\begin{array}{l}\text { B: Lese, skrive og } \\
\text { samtale om } \\
\text { naturvitenskapelige } \\
\text { emner (Kolstø, 2006) }\end{array}$ & $\begin{array}{l}\text { C: Skriving i realfag } \\
(2014)\end{array}$ & $\begin{array}{l}\text { D: Skriving i } \\
\text { naturfag (2012) }\end{array}$ \\
\hline $\begin{array}{l}\text { Antall } \\
\text { ord, } \\
\text { bilde- } \\
\text { bruk, } \\
\text { lenker }\end{array}$ & $\begin{array}{l}2426 \text { ord, } 1 \text { bilde av } \\
\text { skrivende elever, } 7 \\
\text { lenker som ligger fast } \\
\text { i venstre marg på alle } \\
\text { ressurser, } 2 \text { lenker } \\
\text { tilbake til GRF-siden, } \\
1 \text { lenke til } \\
\text { pedagogiske tips. }\end{array}$ & $\begin{array}{l}1614 \text { ord, } 1 \text { bilde av } \\
\text { elever som sitter og } \\
\text { snakker sammen, } 7 \\
\text { lenker som ligger fast } \\
\text { i venstre marg på alle } \\
\text { ressurser, } 2 \text { lenker } \\
\text { tilbake til GRF-siden, } \\
1 \text { lenke til } \\
\text { pedagogiske tips. }\end{array}$ & $\begin{array}{l}692 \text { ord, ingen bilder, } 3 \\
\text { lenker i løpende tekst, } \\
3 \text { i høyre marg som tar } \\
\text { deg til relatert innhold, } \\
6 \text { lenker til ressurser på } \\
\text { naturfag.no, } 4 \text { lenker til } \\
\text { andre ressurser på } \\
\text { skrivesenteret.no }\end{array}$ & $\begin{array}{l}334 \text { ord, } 1 \text { bilde } \\
\text { (skjermdump av } \\
\text { forsøksrapport), } 1 \\
\text { integrert lenke til film } \\
\text { om rapportskriving i } \\
\text { naturfag, } 6 \text { lenker i } \\
\text { høyre marg til relatert } \\
\text { innhold, } 4 \text { lenker til } \\
\text { andre ressurser på } \\
\text { skrivesenteret.no }\end{array}$ \\
\hline Innhold & $\begin{array}{l}\text { Bakgrunns- } \\
\text { informasjon om } \\
\text { grunnleggende } \\
\text { ferdigheter. } \\
\text { Læringsstrategier i } \\
\text { fokus. Eksplisitte } \\
\text { referanser til litteratur } \\
\text { om læringsstrate- } \\
\text { gier. Eksplisitte } \\
\text { referanser til St.meld. } \\
\text { nr. 30, LK06 og } \\
\text { læringsplakaten. }\end{array}$ & $\begin{array}{l}\text { Bakgrunns- } \\
\text { informasjon om } \\
\text { grunnleggende } \\
\text { ferdigheter og } \\
\text { ideer til } \\
\text { undervisningen. } \\
\text { Naturfaglige sjangre } \\
\text { og faglig danning er } \\
\text { fokusert. Teksten har } \\
\text { eksplisitte referanser } \\
\text { til LK06. }\end{array}$ & $\begin{array}{l}\text { Introduksjon til flere } \\
\text { ressurser om skriving i } \\
\text { realfag. Generelle } \\
\text { skriveråd, realfaglig } \\
\text { skrivemåte inkludert } \\
\text { multimodalitet. Vekt } \\
\text { på } \\
\text { presentasjonsskriving } \\
\text { og tenkeskriving. } \\
\text { Lenker til ressurser på } \\
\text { Naturfagsenterets } \\
\text { nettsider. }\end{array}$ & $\begin{array}{l}\text { Introduksjon til } \\
\text { naturfaglig skriving, } \\
\text { med kommentert } \\
\text { læreplansitat. } \\
\text { Videofilm med } \\
\text { tittelen «Elevens } \\
\text { naturfagrapport som } \\
\text { eksempeltekst» er } \\
\text { inkludert som } \\
\text { eksempel. }\end{array}$ \\
\hline
\end{tabular}

Figur 3. Oversikt over inngangstekstene/tekstene fra forstudien

mellom grunnleggende ferdigheter og læringsstrategier, slik det går fram av dette utdraget:

For å synliggjøre sammenhengen mellom læringsstrategier og de grunnleggende ferdighetene, er det naturlig å ta utgangspunkt i de 9 nøkkelprinsippene som ligger til grunn for alt arbeidet med læringsstrategier i undervisninga. Prinsippene er utvikla av Carol Santa i prosjektet CRISS (Creating Independence through Student-owned Strategies)

At det er «naturlig» å ta utgangspunkt i et utvalg prinsipper fra en spesifikk kilde, er en påstand som tydelig promoterer en bestemt pedagogisk retning. Sammen med termen «nøkkelprinsipper» gir denne påstanden signal om at teksten ikke bare framholder læringsstrategier i seg selv, men nettopp Carol Santas versjon som en nødvendig inngang til arbeidet med grunnleggende literacy-ferdigheter. Ord som verktøy og redskaper, og formuleringer som å angripe tekstene, er gjennomgående i tekst A og understreker den strategiorienterte literacy-tenkninga som formidles. Slike metaforer sammenligner lesere og skrivere med håndverkere som trenger spesialtilpassa verktøy og praktiske ferdigheter for å utføre sine oppgaver og nå sine mål. Strategiene som listes opp og eksemplifiseres i ressursen, er studietekniske arbeidsformer 
som TØL- og VØL-skjema, tankekart, styrkenotat, "fri form-kart», skriverammer og kolonnenotat. Eksemplene er knytta til naturfaglige tema som økologi, næringskjeder og frøspredning, men strategiene presenteres som fagovergripende. Idéen som formidles er altså at opplæring i generelle lese- og skrivestrategier er nødvendig for skolens arbeid med å utvikle elevenes lese- og skriveferdigheter i naturfag.

Tekst A oppfordrer samtidig naturfaglærere til å ta i bruk kreative sjangre som fortellinger, rolleskriving og perspektivnotat, for eksempel her:

I et perspektivnotat velger eleven et annet perspektiv enn sitt eget når hun skriver om det som er lært. Etter et arbeid med partikkelmodellen på mellomtrinnet kan elevene for eksempel skrive om mitt liv som luftpartikkel i en ballong eller de kan skrive om livet mitt som dinosaur eller arbeidet med utdødde dyrearter i 3.-4. klasse.

Med henvisning til Santa og Engen (1996) presenteres perspektivnotat og rolleskriving som strategier for å gjøre fagstoffet personlig. Ifølge ressursen er dette noe som bevisstgjør elevene på "perspektiver som avsender, mottaker, budskap og formidlingsmåte». Ressursen sier også eksplisitt at «mange elever trenger å utvide oppfatningen av hva som passer seg i naturfag», og at arbeid med «norskfaglige tema» derfor både kan bidra til fagforståelse og gi motivasjon for skriving i faget. Her kombineres altså tekstens formidling av en læringsstrategidiskurs med en kreativitesdiskurs som er velkjent fra norskdidaktiske diskusjoner om skriveopplæringa, blant annet gjennom begrepet «kreativnorsken» (Moslet, 2009, s. 30-32).

B-teksten fra Naturfagsenteret er tydelig sjangerorientert: Begrepet sjanger er brukt 24 ganger, og fagrelevante sjangre som forklaringer, forskningsartikler, utredninger, beskrivelser og rapporter er listet opp. Forfatteren argumenterer for at kjennskap til og erfaring med fagets sjangre er nødvendig, både for å kunne delta i naturvitenskapelig kommunikasjon og for å kunne vurdere og ta stilling til fagtekster elevene møter:

Et allmenndannende naturfag bør være med på å øke elevenes evne til å delta der naturvitenskapelig kunnskap og ekspertise inngår. [...] Dette innebærer kunnskap om kommunikasjonsformer i naturvitenskap, altså kunnskap om sjangrer som brukes i naturvitenskap. [...] For at elevene skal delta i naturvitenskapelig kommunikasjon gjennom fagets sjangrer, trenger de erfaring med disse

Teksten legger dessuten vekt på at elevene skal lære å forholde seg til fagets tekster på en kritisk og reflektert måte, slik at de blir i stand til å vurdere teksters påvirkningskraft og troverdighet. Skriveopplæringa som anbefales, kombinerer altså sjangerorientering med kritisk lesning av fagtekster. Det siste er ei vektlegging som har fått en forsterket betydning gjennom senere tids interesse for kritisk literacy (jf. LK20).

Skrivesenterets inngangstekst C framstår som ei overordna innledning til andre ressurser om skriving i realfag. Tekstens retoriske oppbygning følger en argumenterende struktur med hovedkomponentene problem-løsning. Problemet som presenteres, er at skolens skriveundervisning har vært forbundet med norsk- og fremmedspråkopplæring, og at «dette kan (vill)lede realfagslærere til å tro at skriveopplæring ikke er deres bord». Ifølge ressursen har språkarbeidet i matematikk og naturfag vært «konsentrert 
om føring av oppgaver, å kunne avlese og tolke kurver og diagrammer, å skrive forklaringer til geometriske konstruksjoner og å skrive lab-rapporter», uten «vekt på å giøre elevene bevisste på fagenes språklige egenart». Løsninga det argumenteres for, er at skriving må integreres i ei realfaglig opplæring for at elevene både skal utvikle kunnskap og kunne presentere den for andre. Med henvisning til Dysthe, Hertzberg og Hoel (2000) omtales dette som tenkeskriving (skrive for å lære) og presentasjonsskriving (lære å skrive). Ressursen framhever også at presentasjonstekster i realfag er preget av høyt presisjonsnivå og nyansert fagterminologi, og at flere modaliteter tas i bruk for å skape mening. Dermed argumenterer den for eksplisitt undervisning i språklige særtrekk og spesifikke realfaglige uttrykksmåter. I så måte målbærer også denne inngangsteksten en sjangerorientert skriveopplæringsdiskurs, men det som står i forgrunnen, er generelle beskrivelser av hva skriving i realfag bør eller må være. Det ser vi ikke minst i gjennomgående påstandsformuleringer som gir uttrykk for sterk grad av nødvendighet: «Elevene må ...», "Elevene trenger å ...», "Læreren må ...» og "skal elevene bli kompetente skrivere [...], må den enkelte faglærer drive eksplisitt skriveundervisning på fagenes premisser». Med sterke antakelser om hva skriveopplæring $\mathrm{i}$ naturfag er og bør være, framstår altså denne teksten som en autoritativ Skrivesenterinstruks for realfagenes arbeid med skriving som grunnleggende ferdighet.

I tekst D fra Skrivesenteret er lingvistiske og tekstlige aspekter framtredende. For det første understreker teksten at det er viktig å undervise elevene i språklige særtrekk ved naturfaglige tekster og hensikten med disse, som nominaliseringer, passivformer og naturfaglige symboler. For det andre løftes kombinasjonen av semiotiske ressurser som bilde, verbaltekst, symboler og modeller fram som et sentralt trekk ved naturfaglige tekster: «Særlig interessant er det å se hvordan eleven tar i bruk ulike meningsbærende ressurser for å beskrive og dokumentere observasjonene han gjør når han undersøker et kalveøye.» Ressursen hevder at eksplisitt undervisning i fagets språk og sjangre forbedrer elevenes mulighet for utvikling og læring, og at skriving «er en nødvendig forutsetning for å synliggjøre kunnskap på en faglig relevant måte».

Eksplisitt undervisning om sjangerrelatert hensikt, struktur og språk er lett gjenkjennelige trekk ved australsk sjangerpedagogikk som vektlegger nettopp språk- og tekstanalyse (Cope \& Kalantzis, 1993; Martin et al., 1987), men ressurs D refererer ikke eksplisitt til denne retningen. Tekstens sjangerfokus er derimot kombinert med referanser til prosessorientert skriveopplæring: «Ved at læreren veileder elevene giennom hele skriveprosessen, fra førskrivefasen til sluttføring av teksten, får elevene hjelp til å forstå hvordan tekstene er bygget opp og hvordan de selv kan konstruere disse tekstene». Samtale om tekst og skriving er løftet fram som en viktig del av slike skriveforløp, og eksempelet som gis giennom den tekstinterne lenken til videofilmen "Elevens naturfagrapport», modellerer en lærer-elevsamtale om språklige valg og formålet med disse valgene.

Når det gjelder forståelsen av naturfaglig literacy og skriving som grunnleggende ferdighet $i$ alle fag, bærer skriveopplæringa som formidles i disse fire ressursene bud om ulike orienteringer og fokus. På den ene siden formidles en strategiorientert 
skriveopplæring som er fagovergripende og ligner den vi finner omtalt i faglitteratur om WAC og CAL (se teorikapitlet). I denne sammenhengen kan vi merke oss hvordan Naturfagsenterets ressurs A henter referanser og sjangre fra norskfaget, som før innføringen av grunnleggende ferdigheter hadde ansvaret for skriveopplæring i skolen. På den andre siden formidles et fag- og danningsorientert syn på literacy med vekt på naturfaglige sjangre og uttrykksmåter. Det fagovergripende perspektivet har fått mindre oppmerksomhet i senere tid, mens danningsperspektivet kan sies å være mer i tråd med nyere forskning om WID og DL, som har et tydeligere fagspesifikt fokus, samtidig som betydningen av skriving som vei til læring anerkjennes. I Skrivesenterets to ressurser (C og D) er denne orienteringa synlig giennom eksplisitt undervisning om språklige særtrekk og fagspesifikke uttrykksmåter. I Naturfagsenterets ressurs $\mathrm{B}$ peker faglige sjangre og kritisk tenkning i samme retning.

\section{Analyse av hele ressursutvalget}

Analysen av inngangstekstene avdekker to ulike orienteringer i sentrenes anbefalinger for skolens skriveopplæring og to ulike fokus i formidlingen av skriving som grunnleggende ferdighet. Disse erfaringene er tatt med videre i form av analysekategorier som er dels teoriforankra og dels empiridrevet. De to første kategoriene er hovedsakelig basert på en empiridrevet sortering av nettressurser etter hvorvidt de primært er strategiorientert eller primært faglig danningsorientert. Slik kan de også relateres til overordna formål med skriveopplæringa. De neste kategoriene dreier seg om skrivefokus, det vil si om fagovergripende eller fagspesifikke aspekter er sentrale i formidlingen av skriving som grunnleggende ferdighet. Dette analysegrunnlaget er utvidet i arbeidet med det fullstendige nettressursutvalget. Med ny empiri oppstod for det første behovet for å opprette en egen orienteringskategori for ressurser der hovedformålet er å skissere bestemte oppgaver og undervisningsopplegg. I forstudien så vi dessuten at inngangstekstene rommet ideer til undervisning så vel som faglig bakgrunnsstoff, trolig fordi de var ment å fungere både som en innføring i grunnleggende ferdigheter og som eksempler på hvordan disse kan operasjonaliseres i naturfagundervisninga. For å undersøke dette nærmere, måtte vi også analysere tekstene med tanke på intendert bruk, og dermed ble bruksområde inkludert som ny kategori.

Analyseresultatene som presenteres i figur 4 (Naturfagsenteret) og figur 6 (Skrivesenteret), er strukturert etter en horisontal og en vertikal akse. Kolonnen til venstre utgjør den vertikale aksen hvor ressursene sorteres i tre kategorier etter hva de framhever som et hovedformål for skriveundervisninga, eller hva de orienterer seg mot: Kategorien prosess og produkt (blå) er orientert mot oppgaver og undervisningsopplegg som legger opp til at elevene skal skrive for eksempel plakat, brosjyre eller forsøksrapport. Kategorien faglig danning (grønn) omfatter ressurser som tematiserer naturvitenskapens faglige egenart og de akademiske disiplinene som ligger til grunn for skolefaget naturfag. Og kategorien strategier (gul) løfter fram lærings- og skrivestrategier som kan danne grunnlag for lærernes undervisning og elevenes skriving. Den horisontale aksen 
viser hva slags fagstoff som presenteres, og hvordan dette blir omsatt til skriveundervisning. I første kolonne presenteres teksten med tittel, samt forfatternavn og årstall når dette er oppgitt. I neste kolonne beskrives tekstens innhold, som deretter er videre kategorisert etter intendert bruksområde, spesifisert som undervisningsideer eller bakgrunnsstoff. Undervisningsideene omfatter konkrete opplegg og mer generelle tips, mens bakgrunnsstoff omfatter disiplinfaglig innhold og mer overgripende stoff om skriving og pedagogikk. De to kolonnene ytterst til høyre (skrivefokus) viser mer spesifikt til hvordan fagstoffet hentes ned i skriveopplæringa, med referanser til skriving i og på tvers av fag, og til fagspesifikk og fagovergripende literacy.

\section{Naturfagsenterets ressurser}

Nedenfor presenteres analysen av de 14 ressursene fra Naturfagsenteret (se figur 4) i tråd med kategoriene vi har beskrevet over.

De analyserte ressursene fra Naturfagsenteret fordeler seg nokså likt mellom de tre orienteringskategoriene til venstre i tabellen: Fire av ressursene er prosess- og produktorienterte, fem ressurser er faglig danningsorienterte og fem er strategiorienterte.

De prosess- og produktorienterte ressursene gir konkrete ideer til undervisning uten utdypende bakgrunnsstoff. I tre av dem (E, F, G) er det allerede i overskriften tydelig at aktivitetene som presenteres skal munne ut $\mathrm{i}$ et bestemt produkt: «Lag en brosjyre» (E), "Lag plakat ...» (F) og "Å lage et sammendrag» (G). Skrivefokuset i alle de fire ressursene er fagovergripende i den forstand at ideene som presenteres i prinsippet kan brukes i hvilket som helst fag. I så måte er ressurs $G$ et tydelig eksempel. På et overordnet, generelt nivå gir den tips om at elever kan ha nytte av å lage sammendrag av en lærers foredrag. Dette knyttes imidlertid ikke til naturfaglig innhold eller naturfagets språk og tekster. Ressurs E viser til at "[å]lage brosjyrer er en fin aktivitet for å bevisstgjøre elevene om at skriving er en prosess». Med henvisning til generelle skrivedidaktiske råd som å innhente og bearbeide informasjon, bruke kilder og bestemme formål, løfter teksten fram at sjangeren «egner seg godt for samarbeid mellom naturfag og norsk». To av ressursene $(\mathrm{F}$ og $\mathrm{H})$ har et noe mer fagspesifikt innhold, men kan likevel ikke sies å ha et fagspesifikt skrivefokus. Ressurs F skilter tydelig at den tematiserer naturfaglig språk, herunder de fagspesifikke begrepene universet og verdensrommet (se skjermdump i figur 5 under). Disse begrepene er nevnt $i$ en meny med ordforklaringer i høyre marg, men de blir ikke vist til eller utdypet $\mathrm{i}$ brødteksten, og dermed er de heller ikke fullstendig integrert $\mathrm{i}$ formidlinga av det skrivedidaktiske opplegget.

Ressurs $\mathrm{H}$ viser hvordan observasjoner av naturfenomener kan kombineres med å beskrive det man har sett, der «hvert motiv bør ha en beskrivende tekst som inneholder naturfagsord». Teksten løfter fram at "[n]ysgjerrighet og engasjement som stimuleres gjennom fakten på bokstaver og tall i naturen kan være et fint utgangspunkt for videre utforskende aktiviteter og skriving» og inkluderer et eksempel på hvordan slikt arbeid kan munne ut $\mathrm{i}$ en lengre naturfaglig tekst. Forgrunnen i skriveaktivitetene 


\begin{tabular}{|c|c|c|c|c|c|c|}
\hline \multirow{2}{*}{ 产 } & \multirow[b]{2}{*}{$\begin{array}{l}\text { Ressurs } \\
\text { (tiittel, forf., àr) }\end{array}$} & \multirow[b]{2}{*}{ Beskrivelse av innhold } & \multicolumn{2}{|c|}{ Bruksomräde } & \multicolumn{2}{|c|}{ Skrivefokus } \\
\hline & & & $\begin{array}{l}\text { Under- } \\
\text { visn-- } \\
\text { ideer }\end{array}$ & $\begin{array}{l}\text { Bakgr.- } \\
\text { stoff }\end{array}$ & $\begin{array}{l}\text { Fag- } \\
\text { spesif. }\end{array}$ & $\begin{array}{l}\text { Fag- } \\
\text { overgr. }\end{array}$ \\
\hline \multirow{4}{*}{ 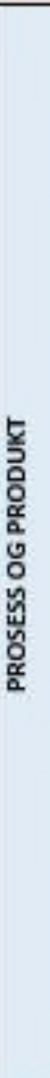 } & $\begin{array}{l}\text { E: Lag en brosjyre (Mork } \\
\text { \& Erlien, 2010) }\end{array}$ & $\begin{array}{l}\text { Veiledet skriveprosess. Generelle } \\
\text { skrivedidaktiske ràd. Vekt pá brosiyre- } \\
\text { format (mal) framfor naturfaglig innhold. } \\
\text { Eksplisitte referanser til LKO6. }\end{array}$ & $\mathrm{x}$ & & & $\mathrm{x}$ \\
\hline & $\begin{array}{l}\text { F: Lag plakat om en ut- } \\
\text { forsking av verdens- } \\
\text { rommet (Kvande \& } \\
\text { 5orborg, u.a.). }\end{array}$ & $\begin{array}{l}\text { Vekt pá utforskende læreprosesser og } \\
\text { generalle lese-og skrivestrategier. Knytta til } \\
\text { tema fra læreplanen. Plakat som mal og } \\
\text { produkt. Det naturfaglige ligger primæert i } \\
\text { illustrasjonene (elevarbeid) og i lenker og } \\
\text { ordforklaringer i margen, mens brødteksten } \\
\text { fokuserer mer generelt pá prosess og } \\
\text { produkt. }\end{array}$ & $\mathrm{x}$ & & & $\mathrm{x}$ \\
\hline & $\begin{array}{l}\text { G: A lage et sammendrag } \\
\text { (Folkvord \& Mahan, } \\
\text { 2006) }\end{array}$ & $\begin{array}{l}\text { Idè til elevoppgave. Lage sammendrag } \\
\text { basert pá notater fra lærerforedrag. } \\
\text { Generelle skrivedidaktiske rảd (naturfag ikke } \\
\text { nevnt). }\end{array}$ & $\mathrm{x}$ & & & $\mathrm{x}$ \\
\hline & $\begin{array}{l}\text { H: Engasjerende } \\
\text { utgangspunkt for } \\
\text { skriving! (Mork, 2015) }\end{array}$ & $\begin{array}{l}\text { Beskriver en aktivitet der elevene tar bilder } \\
\text { av naturelementer som ligner tall og } \\
\text { bokstaver. Motivene settes sammen til } \\
\text { digitale presentasjoner eller plakater, og } \\
\text { elevene skriver tekster som beskriver } \\
\text { motivene. Ideer til ytterligere utforsking og } \\
\text { skriving med bakgrunn i tall- og } \\
\text { bokstavjakten. Eksplisitte referanser til } \\
\text { Lko6. }\end{array}$ & $\mathrm{x}$ & & & $\mathrm{x}$ \\
\hline \multirow[b]{2}{*}{ 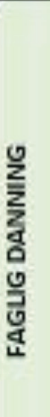 } & $\begin{array}{l}\text { Inngangstekst B: Lese, } \\
\text { skrive og samtale om } \\
\text { naturvitenskapelige } \\
\text { emner (Kolstø, 2006) }\end{array}$ & $\begin{array}{l}\text { Bakgrunnsinformasjon om grunnleggende } \\
\text { ferdigheter og ideer til undervisningen. } \\
\text { Naturfaglige sjangre og danning i fokus. } \\
\text { Eksplisitte referanser til LKO6. }\end{array}$ & $(\mathrm{X})$ & $x$ & $\mathrm{x}$ & \\
\hline & $\begin{array}{l}\text { I: Huorfor argumentasjon } \\
\text { inaturfag? (Mork, 2009) }\end{array}$ & $\begin{array}{l}\text { De fire ressursene ( }(-L) \text { inngár i en } \\
\text { samleressurs som bestár av } 11 \text { artikler som } \\
\text { tematiserer argumentasjon. (I) og (K) er } \\
\text { oggá skilt ut som egne ressurser. Alle de fire } \\
\text { tekstene er relatert til LKos og er } \\
\text { gjennomsyret av naturfaglig tenkning. }\end{array}$ & & $\bar{x}$ & $\bar{x}$ & \\
\hline
\end{tabular}




\begin{tabular}{|c|c|c|c|c|c|c|}
\hline & $\begin{array}{l}\text { : Hvordan tilrettelegge } \\
\text { for argumentasjon i } \\
\text { undervisningen? (Mork, } \\
2009 \text { ) }\end{array}$ & & $\mathrm{X}$ & $\mathrm{X}$ & & $\bar{x}$ \\
\hline & $\begin{array}{l}\text { K: Skriving av } \\
\text { eksperimentrapporter } \\
\text { som opplæring i } \\
\text { argumentering (Kolsto, } \\
\text { 2009) }\end{array}$ & & $(X)$ & $\mathrm{X}$ & $\bar{x}$ & \\
\hline & $\begin{array}{l}\text { L: Gi din stemme for } \\
\text { naturfaget i skolen - en } \\
\text { retorisk hyllest til } \\
\text { naturfaglig opplysning } \\
\text { (Flyum, 2010) }\end{array}$ & & & $\mathrm{X}$ & & $\bar{x}$ \\
\hline & $\begin{array}{l}\text { Inngangstekst A: } \\
\text { Naturfag, } \\
\text { læringsstrategier og } \\
\text { grunnleggende } \\
\text { ferdigheter (Nergàrd, } \\
\text { 2006) }\end{array}$ & $\begin{array}{l}\text { Bakgrunnsinformasjon om grunnleggende } \\
\text { ferdigheter. Læringsstrategier i fokus. } \\
\text { Eksplisitte referanser til litteratur om } \\
\text { lærings-strategier. Eksplisitte referanser til } \\
\text { st.meld. nr. 30, LKO6 og læringsplakaten. }\end{array}$ & $\bar{x}$ & & & $\bar{x}$ \\
\hline & $\begin{array}{l}\text { M: «Du vet ikke hva du } \\
\text { har skjønt for du har satt } \\
\text { ord pà det!* } \\
\text { (Hertzberg, 2006) }\end{array}$ & $\begin{array}{l}\text { 5má øvelser (mikro-oppgaver) for à fremme } \\
\text { skriving som redskap for læring. Primært } \\
\text { generelle skrivedidaktiske ràd, med } \\
\text { referanser til naturfaglige begreper som } \\
\text { hypoteser og utforskning. }\end{array}$ & $\mathrm{X}$ & & & $\mathrm{X}$ \\
\hline 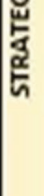 & $\begin{array}{l}\text { N: Grunnleggende } \\
\text { ferdigheter i teknologi og } \\
\text { design (Bach, u.ă.) }\end{array}$ & $\begin{array}{l}\text { Tematiserer hvordan man pá tvers av fag } \\
\text { bruker de grunnleggende ferdighetene som } \\
\text { redskaper for à planlegge, utvikle og } \\
\text { produsere hverdagsprodukter. Knyttet til } \\
\text { læreplanmàl. }\end{array}$ & $x$ & & & $\bar{x}$ \\
\hline & $\begin{array}{l}\text { D: Bruk av BISON-blikk } \\
\text { pă naturfaglige tekster } \\
\text { (Braute \& Dahl, u.à.) }\end{array}$ & $\begin{array}{l}\text { Tematiserer lesestrategien BISON, men viser } \\
\text { ogsả hvordan elevene kan ta med } \\
\text { elementer herfra over i egen skriving. } \\
\text { Generelle skriverăd, noen naturfaglige } \\
\text { eksempler/begrep. Knyttet til læreplanmàl. }\end{array}$ & $x$ & & & $\bar{x}$ \\
\hline & $\begin{array}{l}\text { P: Digitalt tankekart } \\
\text { (Hoff, 2009) }\end{array}$ & $\begin{array}{l}\text { Eksempler pá programmer som kan brukes } \\
\text { for à lage digitale tankekart. }\end{array}$ & $x$ & & & $\mathrm{x}$ \\
\hline
\end{tabular}

Figur 4. Analyse av ressurser fra naturfagsenteret.no 


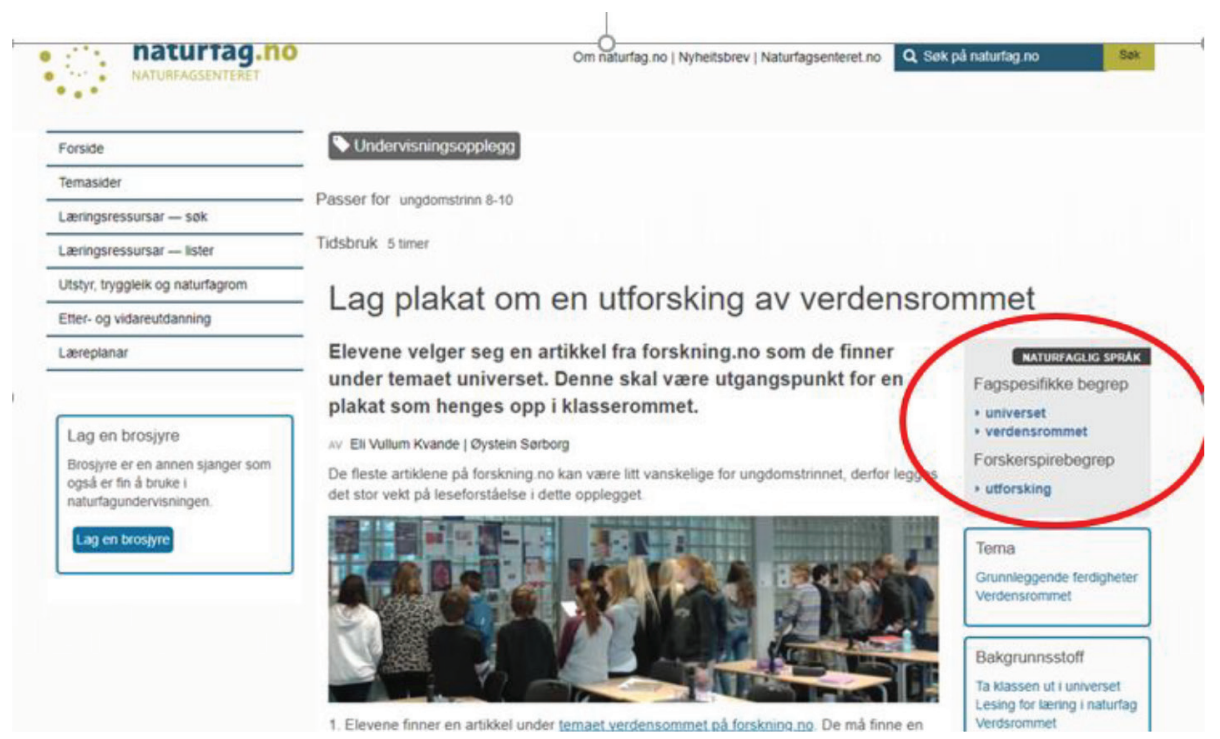

Figur 5. Skjermdump av ressursen «Lag plakat om en utforsking av verdensrommet» (vår innsirkling)

som presenteres i ressursen, er imidlertid ikke det fagspesifikke innholdet, men hvordan naturobservasjoner kan motivere til skriving og kombineres med tankekart, skriverammer og «femavsnittsmetoden» (Flyum, 2011) for å hjelpe elevene til å skrive tekster med god struktur og sammenheng.

De fem danningsorienterte ressursene, det vil si inngangstekst $\mathrm{B}$ og de fire ressursene om argumentasjon ( $\mathrm{I}, \mathrm{J}, \mathrm{K}$ og L), rommer bakgrunnsstoff som beskriver både skriving, argumentasjon og kritisk lesning som viktige bestanddeler i naturfagsundervisninga. Ressursene $\mathrm{B}$ og $\mathrm{K}$ har et fagspesifikt skrivefokus med vekt på at elevene bør få lære hvorfor naturvitere skriver. Forfatteren, som er den samme for begge, reiser spørsmål om hvorvidt elevenes lab-rapporter er en naturvitenskapelig sjanger eller en skolesjanger. Han peker på at formen ligner den vi kjenner fra vitenskapelige artikler, men at utforsking og utvikling av ny kunnskap ikke er tilstrekkelig vektlagt. I tråd med kompetansemål fra læreplanen tar han derfor til orde for at elevene må lære å «skrive rapporter etter modell av naturvitenskapelige eksperimentrapporter». Ved å bruke både egne observasjoner og relevant fagstoff kan de her knytte sammen skolefaget og vitenskapsfaget. Begge disse ressursene har også innslag av konkrete tips til undervisninga (derav kryss i parentes for undervisningsideer), og begge løfter fram nødvendigheten av at elevene skal oppøve evnen til å vurdere påstander og stille kritiske spørsmål.

De to siste danningsorienterte ressursene ( $\mathrm{J}$ og L) har et fagovergripende skrivefokus. Ressurs J løfter fram ideer til arbeid med skriftlig argumentasjon som «tvinger elevene til å tenke over språket de bruker» og gjør «at de begrunner konklusjonene sine». Deler av tekstens innhold er hentet fra boka Lceringsstrategier og selvregulert laring (Elstad \& Turmo, 2006), og ressursen presenterer, i likhet med flere andre 
Naturfagsenter-ressurser, et tokolonne-notat som eksemplifiserer det vi tidligere har beskrevet som generelle lærings- og skrivestrategier. Ressurs L omtaler laboratorierappporten, men i motsetning til forfatteren av inngangsteksten (B) og ressurs (K) som behandler denne sjangeren på fagspesifikt vis, fokuserer forfatteren av ressurs L på en empirisk-naturvitenskapelig artikkelstruktur - IMRAD - som kan benyttes i ulike fag. Vi ser altså at selv om ressursene er kategorisert med et fagovergripende skrivefokus, kan de likevel ha et fagspesifikt innhold, slik vi var inne på i omtalen av de prosess- og produktorienterte ressursene. Ressursene tematiserer naturfaglig danning og naturfagets egenart, men uten at det blir lagt vekt på hvordan dette kan operasjonaliseres fagspesifikt i skriveopplæringa.

De strategiorienterte ressursene (A, M, N, O, P) inneholder ideer til undervisning, men uten å skissere helhetlige undervisningsopplegg. I analysen av inngangstekst $\mathrm{A}$ har vi tidligere sett hvordan læringsstrategier tydelig løftes fram. Også i de øvrige ressursene i denne kategorien er generelle lese-, skrive- og læringsstrategier i fokus, og $\mathrm{i}$ den grad skriving blir tematisert, er det på et fagovergripende plan. Ressurs M presenterer skriveøvelser som ifølge forfatteren er velkjente innenfor WAC-tradisjonen, og skisserer læringsstimulerende oppgaver (tenkeskriving og logg) som kan brukes $\mathrm{i}$ alle fag med tilpasning til de aktuelle temaene det arbeides med. Ressurs $\mathrm{N}$ tematiserer hvordan skriving, og de fire andre grunnleggende ferdighetene, kan benyttes som tverrfaglige redskaper i en design- og produksjonsprosess, og ressursene $\mathrm{O}$ og $\mathrm{P}$ viser til fagovergripende strategier for bearbeiding og strukturering av lærestoff (BISONblikk og digitale tankekart) som kan hentes ned og knyttes til skriving i naturfag.

Når vi oppsummerer analysene av ressursene fra Naturfagsenteret, ser vi at de to hovedsporene vi fant gjennom analysene av inngangstekstene - én fagovergripende og én fagspesifikk retning - blir tydeliggjort. De prosess- og produktorienterte og de strategiorienterte ressursene bærer sammen oppe en skriveopplæringspraksis som dreier seg om å bruke skriving som verktøy i læringsprosesser. Her ser vi også at det hentes elementer fra norskfaglig skriving, med vekt på kreativitet. Alle ressursene, så nær som to, inneholder konkrete ideer til undervisning, ofte eksemplifisert gjennom generelle skrivedidaktiske råd. Det naturfaglige innholdet kommer tydeligst til uttrykk i de fem danningsorienterte ressursene som tematiserer naturfagets egenart og faglig emnekunnskap. Tre av disse (K, B, I) operasjonaliserer det vi omtaler som et fagspesifikt skrivefokus. Både disse og de to andre danningsorienterte ressursene tar til orde for at undervisninga må legge vekt på elementer som kan bidra til oppøving av kritisk tenkning og demokratisk medborgerskap, slik som å vurdere og ta stilling til informasjon i media og andre steder samt å fremme egne veloverveide argumenter.

\section{Skrivesenterets ressurser}

De fem ressursene fra Skrivesenteret er analysert på tilsvarende måte som ressursene fra Naturfagsenteret. Resultatene, som er framstilt i figur 6, gir imidlertid et noe annet helhetsbilde. 


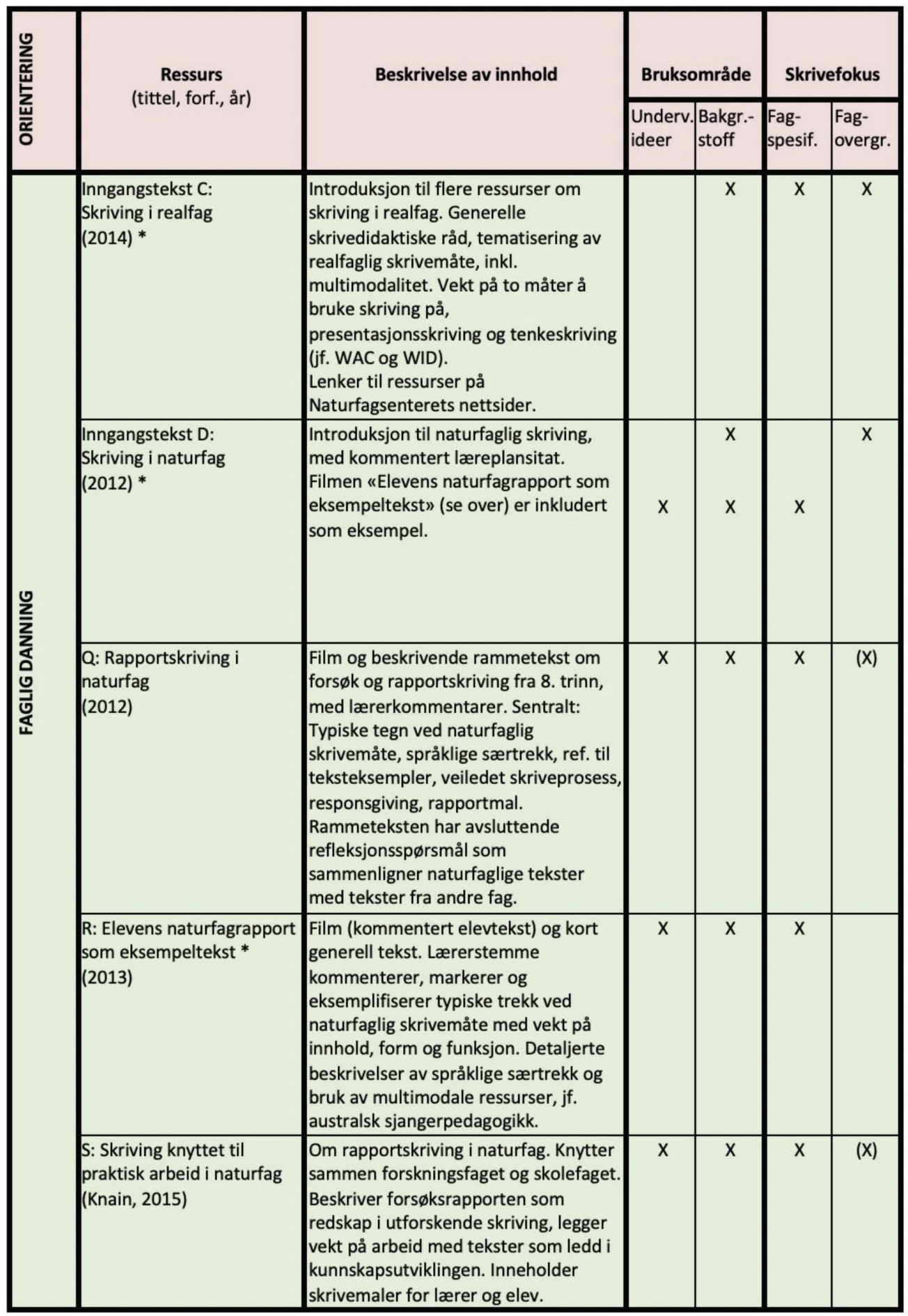

Figur 6. Analyse av ressursene på skrivesenteret.no 
Som det går fram av oversikten, er alle Skrivesenter-ressursene kategorisert som orienterte mot faglig danning. Alle ressursene har også et fagspesifikt skrivefokus, og de er dermed eksplisitt forankra i oppdraget om å utvikle ressurser om skriving i naturfag. Samtidig er flertallet av ressursene også fagovergripende ved at de drar veksler på generell skrivedidaktisk kunnskap.

Tre av ressursene (merket med stjerne) er ganske like i utforminga. Disse er overlappende, både rent praktisk fordi videoressursen som er omtalt som ressurs R, inngår som eksempel i inngangstekst $\mathrm{D}$, og ved at alle ressursene løfter fram språklige særtrekk ved naturfagenes tekstkulturer. Det gjelder for eksempel bruk av faguttrykk og presis formidling av observasjoner. Fagspråket som benyttes her, kan karakteriseres som et funksjonelt orientert grammatisk metaspråk, og det blir blant annet vist til bruk av nominaliseringer, passivformer og ulike multimodale ressurser. To av ressursene tar til orde for "en synlig og eksplisitt undervisning i fagenes språk og sjangrer» (inngangstekst $\mathrm{C}$ og $\mathrm{D}$ ), og alle ser skriving som en forutsetning for å presentere naturfaglig kunnskap på en relevant måte.

De tre nevnte ressursene viser også, direkte eller indirekte, til skriving innenfor og på tvers av fag. Inngangstekst $\mathrm{C}$ fokuserer på forholdet mellom å lære å skrive og å skrive for å lære, som vi kjenner fra omtalen av WAC og WID. Dette er tydelig allerede $\mathrm{i}$ ingressene til to av ressursene $(\mathrm{C}$ og $\mathrm{D})$. For eksempel innledes ressurs $\mathrm{D}$ med spørsmålet om «[h]vordan man kan legge til rette for en undervisning der elevene får bruke skriving som redskap for å utvikle kunnskap i faget». Ved å fokusere på skriving som en kompleks læringsaktivitet løfter alle de tre ressursene fram skriving som vei til faglig kunnskap og danning. Sentralt her står innføring i naturfaglige sjangre og tenkemåter, med særlig vekt på språklig og tekstlig uttrykk.

Ressurs Q tar utgangspunkt i en film fra gjennomføringa av et undervisningsopplegg om forsøk og rapportskriving. Den rommer både ideer til undervisning og bakgrunnsstoff, og skrivefokuset kan sies å være både fagspesifikt og fagovergripende. Krysset i parentes viser her til at filmen har et fagspesifikt fokus, mens rammeteksten er fagovergripende. En slik helgardering henger sammen med at dette er en omfattende ressurs, der generelle skriveråd gis parallelt med omtale av fagspesifikk undervisning. Fordi ressursen presenterer et helhetlig undervisningsopplegg som munner ut i skriving av eksperimentrapport, kunne den i prinsippet vært kategorisert som prosess- og produktorientert, men vi har kategorisert den som faglig danningsorientert fordi den først og fremst tematiserer naturfagenes språklige egenart, og hvordan dette kommer til uttrykk i fagets tekster. Allerede i ressursens første setning blir det slått fast at "[d]et å kunne et fag er å kunne uttrykke seg skriftlig og muntlig på fagets premisser». Her ser vi klare paralleller til diskusjonen om literacy-forankringa av LK06, som vi refererte til innledningsvis. Mer spesifikt framheves betydningen av å diskutere typiske kjennetegn ved naturfaglige skrivemåter med elevene, og i undervisningsopplegget som presenteres, gir elevene respons på hverandres rapporter med dette for øye.

Ressurs $S$ skiller seg noe fra de øvrige Skrivesenter-ressursene. Den søker å knytte sammen vitenskapsfaget og skolefaget og legger vekt på elevenes faglige refleksjoner 


\section{Lorentzen, M. -A. Igland og R. Solheim}

knytta til praktisk arbeid i naturfag. Dermed er den tydelig orientert mot faglig danning, og arbeidet med skriving er tett knytta til elevenes utforskende arbeid. Samtidig rommer den konkrete eksempler i form av fagovergripende skrivemaler som er grafisk uthevet i teksten (derav kryss i parentes under fagovergripende skrivefokus). Slik viser ressursen hvordan naturvitenskap kan operasjonaliseres i skolen. Sammenlignet med de fire ovennevnte ressursene er denne mindre eksplisitt når det kommer til fokus på språk og tekst. I stedet løfter den fram elevenes læringsprosesser. Dette har den til felles med de danningsorienterte ressursene fra Naturfagsenteret (se figur 4), og i denne sammenhengen er det verdt å merke seg at dette er den eneste Skrivesenter-ressursen som har en navngitt ekstern forfatter med naturvitenskapelig bakgrunn.

Oppsummerende kan vi si at Skrivesenterets ressurser samla sett bærer oppe en språk- og tekstbasert skriveopplæringsdiskurs som er pedagogisk og ideologisk forankra i en fagspesifikk literacy-orientering. Skriveoppæringspraksisen som anbefales, innebærer en gjennomgående formålstenking med vekt på eksplisitt undervisning $\mathrm{i}$ naturfaglige tenke- og skrivemåter samt opplæring i bestemte sjangre med tilhørende verbalspråklige og multimodale ressurser. I flere av ressursene fra Skrivesenteret kan vi se spor av australsk sjangerpedagogikk, spesielt gjennom vektleggingen av spesifikke sjangrer, tekststrukturer og faglige uttrykksmåter (Cope \& Kalantzis, 1993; Martin et al., 1987). Den disiplinfaglige forankringa er først og fremst knytta til fagspråket, mens det naturfaglige innholdet i mindre grad blir tematisert - selv om videoeksempelet (ressurs R / inngangstekst D) omhandler en elevtekst som naturfaglig sett må regnes som avansert. En forståelse av hva som er gode naturfagstekster, ligger innbakt i disse ressursenes språk- og tekstorientering, samtidig som de på tydelig vis formidler hva Skrivesenteret, med sitt fagovergripende mandat, legger i fagrelevant skriving - altså skriving som grunnleggende ferdighet i naturfag. ${ }^{8}$

\section{Drøfting og faglige implikasjoner}

Naturfagsenteret og Skrivesenteret har ulike mandat og ansvar for ulike faglige domener, henholdsvis naturfaget $i$ skolen og skriving som grunnleggende ferdighet $i$ alle fag. Slik sett kan ikke virksomhetene sammenlignes direkte. Det er likevel relevant å studere hvordan skriving og skriveopplæring i naturfag er forstått og formidlet i de to sentrenes nettressurser, og hvordan de sammen og hver for seg bidrar til å realisere mandatene og sette utdanningspolitikken i spill.

Analysene vi har presentert, gir innsyn i sentrenes rolle som medierende ledd mellom offentlig utdanningspolitikk og undervisningspraksis, eller i forholdet mellom sosiale strukturer og sosial praksis (Fairclough, 2003). Overført til klasserommet,

\footnotetext{
${ }^{8}$ Også Skrivesenterets nettsted har ressurser som er orienterte mot lærings- og skrivestrategier, så vel som prosess og produkt, men ingen av disse inngår i ressursutvalget som omhandler skriving i naturfag.
} 
og sett i et literacy-perspektiv, kan ressursene bidra til forming av ulike literacypraksiser (Barton, 2007). Nettressursene som inngår i denne studien, har ulik faglig og teoretisk forankring og formidler ulike forståelser av skriving og skriveopplæring i skolens naturfag. Gjennom ulike skrivefokus, ulike faglige og didaktiske orienteringer, og med støtte i generell skrivedidaktikk, læringsstrategier og fagdidaktikk, bidrar de to sentrene til operasjonalisering av de læreplanforankra grunnleggende ferdighetene. De strategiorienterte ressursene har for en stor del preg av øving og oppfordringer til skriving som ledd i læringsarbeidet, mens de språk- og danningsorienterte ressursene i større grad legger vekt på at elevene skal lære å uttrykke seg på relevante måter, gjerne gjennom lengre tekster, i sjangre og uttrykksmåter som er relevante i naturfag. Vi ser at sentrene på ulike måter søker å knytte sammen naturfaglig innhold og språklig realisering av faget. Dermed legger de ulike føringer for naturfaglige skrivepraksiser.

I bildet som framkommer i analysen av Naturfagsenterets ressurser (jf. figur 4), ser vi at tekstene fordeler seg nokså jevnt mellom de ulike orienteringene. Naturfaglig innhold er nevnt i alle med unntak av i ressurs G. Når det kommer til operasjonalisering av faget gjennom skriveopplæringa, er det imidlertid generelle lærings- og skrivestrategier som dominerer, dels med støtte i norskfaglige skrivemåter, hvilket gir grunn til å spørre om ressursene gir lærerne god nok hjelp til å innlemme elevene i fagets tekstkultur (jf. Knain, 2005a; Lykknes, 2015). Senteret formidler altså en skriveopplæringspraksis med til dels avansert faglig innhold, mens det i liten grad legges vekt på hvordan dette kan løftes fram verbalt og multimodalt $i$ arbeid med fagets tekster.

Skrivesenter-ressursene er mer entydig orienterte mot faglig danning, noe som tydelig går fram av analysebildet i figur 6 . I tråd med grunntanker om fagspesifikk literacy, vektlegges elevenes evner til å ta del i naturfaglige kontekster, tenkemåter og tekstlige praksiser (Fang, 2012, s. 19). Ressursene synliggiør gjennomgående lingvistiske og multimodale særtrekk ved naturvitenskapelige uttrykksmåter. Samtidig har flere av dem også et fagovergripende skrivefokus ved at de støtter seg på generell skrivedidaktisk kunnskap. I skriveopplæringspraksisene som formidles, ligger altså hovedvekten på språk- og tekstbasert opplæring. Det disiplinfaglige innholdet, derimot, blir primært presentert gjennom eksempel på hva som kjennetegner realfaglige uttrykksmåter.

Hva som utgiør forgrunn og bakgrunn i ressursene, kan også fortolkes i lys av utdanningspolitiske føringer over tid. Inngangstekstene fra Naturfagsenteret ble publisert i 2006, altså like etter Kunnskapsløftets innføring av grunnleggende ferdigheter. Skrivesenterets tekster er publisert i perioden 2012-2014. På det tidspunktet hadde følgeforskning fastslått at begrepet grunnleggende ferdigheter i mange sammenhenger var snevert forstått, og at innføringa i liten grad førte til endringer i lærernes praksis (Møller et al., 2010). I forbindelse med læreplanrevisjonen i 2013, var det derfor et hovedanliggende å synliggjøre forbindelsen mellom grunnleggende ferdigheter og fagplanenes progresjon, og et eget rammeverk for grunnleggende ferdigheter ble utvikla i 2012 (Utdanningsdirektoratet, 2012/2017). Både Naturfagsenteret og 


\section{Lorentzen, M. -A. Igland og R. Solheim}

Skrivesenterets inngangstekster ble imidlertid publisert før dette. Med tanke på at disse ressursene gir en introduksjon til arbeid med grunnleggende ferdigheter i faget, og at de fremdeles blir prioritert av brukerne (jf. lærernes valg i forstudien), kan det synes påfallende at sentrene $\mathrm{i}$ liten grad har oppdatert disse $\mathrm{i}$ tråd med den utdanningspolitiske diskusjonen, erfaringer fra skolene og forskning på feltet. ${ }^{9}$

Det er også interessant å reflektere over hva som ikke nevnes i ressursene. Fra stortingsmeldinga som innvarslet de grunnleggende ferdighetene (Meld. St. 30 (2003-2004)) og gjennom hele tidsspennet våre analyser omfatter, har literacy vært et utdanningspolitisk kjernebegrep. Det har vært framtredende i skriveforskning og i teorier som ligger til grunn for læreplanene, og det har vært knytta til læreplanen gjennom forskning og faglig debatt (jf. f.eks. Berge, 2005). Det er således grunn til å anta at teorier om literacy danner et bakteppe for arbeidet til de nasjonale sentrene. Slike perspektiv er ikke nevnt eksplisitt i de analyserte ressursene. I de danningsorienterte ressursene fra Naturfagsenteret løftes det imidlertid fram at elevene må få trening i å tenke kritisk, stille spørsmål og reflektere over naturfaglig forskning og ulike typer fagtekster. Slike sporer til oppøving av kritisk literacy finner vi ikke i de mer språkorienterte ressursene fra Skrivesenteret. Kritisk kompetanse er derimot vektlagt både i den nye overordna delen av læreplanverket (Utdanningsdirektoratet, 2017) og fornyelsen av læreplanen (LK20). Det er også i tråd med nyere literacy-forskning, både nasjonalt og internasjonalt (Blikstad-Balas, 2018; Peterson et al., 2018).

I en drøfting av sentrenes forvaltning av utdanningspolitikken, og i en diskurskritisk tilnærming, er det interessant å stille spørsmål om hvorvidt ulike syn på literacy kan ha bidratt til ulike tolkninger og realiseringer av sentrenes mandat. I prosessen fram mot fagfornyelsen i 2020 har ulike forståelser av fagspesifikke kompetanser vært gjennomgående tema (NOU 2014: 7; NOU 2015: 8; Meld. St. 28 (2015-2016)). Også LK06, som ligger til grunn for ressursene som er analysert i denne studien, løfter fram både fagspesifikke og fagovergripende perspektiver. Gjennom våre analyser ser vi at Naturfagsenterets ressurser - noe overraskende - synliggiør det vi omtaler som et fagovergripende skrivefokus, mens Skrivesenterets ressurser i større grad har et fagspesifikt fokus. Imidlertid kan det sies å være i tråd med forventningene at det faglige innholdet i Skrivesenterets ressurser kommer i bakgrunnen, til fordel for framheving av språklige og tekstlige særpreg ved naturfaglige uttrykksmåter.

I lys av de senere års vekt på fagspesifikke tekstkulturer og fagspesifikk skriving, kan det synes paradoksalt at Naturfagsenteret ikke i større grad tar utgangspunkt i fagets egenart for å operasjonalisere skriveopplæringa, og at ressursene ikke er oppdatert i tråd med nyere forskning og utdanningspolitikk. En mulig årsak til at senteret $i$ utgangspunktet vendte seg til generelle læringsstrategier og til norskfaget, er at det er disse instansene som tradisjonelt har formidla kunnskap om skriving. En annen årsak

\footnotetext{
${ }^{9}$ Ingen av ressursene i utvalget er publisert etter 2015. Begge inngangstekstene fra Naturfagsenteret, som av lærerne i studien ble løftet fram som sentrale kilder, er fra 2006.
} 
peker talspersoner fra miljøet på selv: På tross av den formende rollen skriftspråket spiller i vitenskapen, har arbeid med tekster tradisjonelt hatt lite fokus i naturfaget (Sørvik \& Mork, 2015). Likevel var Naturfagsenteret tidlig ute med å tematisere faglig literacy og skriving i fagene. Gjennom navngitte forfattere bringer ressursene også inn ulike fagstemmer. Slik bidrar de både til større mangfold og til en annen form for intertekstualitet enn i Skrivesenterets mer ensarta ressurser, der senteret som regel står som utgiver.

Oppsummerende, og i et overordna perspektiv, kan man si at hovedforskjellen mellom skriveopplæringspraksisene som formidles gjennom de to sentrenes nettressurser for ungdomstrinnet, ligger på faglig innhold versus faglig uttrykk. Naturfagsenterets vekt på faglig innhold realiseres gjennom ressurser som løfter fram faglige ferdigheter og faglig danning, men gjennom et fagovergripende skrivefokus, mens Skrivesenterets språkbaserte inngang til naturfaget synes å være forankra i tankegods fra australsk sjangerpedagogikk og forskning på fagspesifikk literacy.

I denne artikkelen har vi løftet fram forskjeller og likheter mellom to nasjonale sentre, slik de framtrer i analyser av et begrenset utvalg nettressurser rettet mot ungdomstrinnet. Videre studier av ressurser for andre trinn i skoleløpet vil kunne bidra til å nyansere eller underbygge våre konklusjoner. En sentral utfordring i arbeid med faglig literacy i skolen, uavhengig av nivå, er likevel å knytte sammen innhold og uttrykk, slik at elevene blir i stand til å gienkjenne, uttrykke seg i og gjøre seg nytte av fagets diskurser. Det stiller store krav til kunnskap både om fagets innholds- og uttrykksside, og det krever et metaperspektiv på den faglige helheten så vel som på faglig danning. For at lærerne skal lykkes med en slik fagspesifikk opplæring i naturfagenes språk og tekstkulturer, trenger de støtte i gode undervisningsressurser. De nasjonale sentrene, som fortolkere og forvaltere både av relevant literacy-forskning og nasjonal utdanningspolitikk, har her en viktig rolle i å bistå skoler og lærere som skal sette kunnskapen i spill. Våre analyser tyder på at Naturfagsenteret og Skrivesenteret, med hver sine mandat og hver sine faglige styrker, i enda større grad kan utfylle hverandre i dette arbeidet - som aktive formidlere av oppdatert kunnskap om skriving i naturfag.

\section{Forfatteromtale}

Vibeke Lorentzen er ph.d.-stipendiat ved Institutt for lærerutdanning, NTNU. Lorentzen har lang undervisningserfaring fra grunnskolen. Hun har skrevet artikler om skriveopplæring og skrivedidaktikk og utviklet flere pedagogiske ressurser om skriveopplæring.

Mari-Ann Igland er professor ved Institutt for lærerutdanning, NTNU. Igland har lang erfaring fra lærerutdanningsfeltet, og hun har publisert en rekke arbeider om lærerrespons i ulike format, skriftlig argumentasjon, literacy, sosiokulturell teori og dialogteori. 


\section{Lorentzen, M. -A. Igland og R. Solheim}

Randi Solheim er professor ved Institutt for lærerutdanning, NTNU. Solheim har bakgrunn fra sosiolingvistikk og skriveforskning, og hun har publisert en rekke arbeider om språkdidaktikk, skriveopplæring og vurdering av skriving.

\section{Referanser}

Barton, D. (1994). Literacy: an introduction to the ecology of written language (1. utg.). Blackwell.

Barton, D. (2007). Literacy: an introduction to the ecology of written language (2. utg.). Blackwell.

Bean, T.W., Readence, J. E., \& Baldwin, R. S. (2011). Content area literacy: An integrated approach. Kendall Hunt Publishing Company.

Berge, K. L. (2005). Skriving som grunnleggende ferdighet og som nasjonal prøve - ideologi og strategier. I A. J. Aasen \& S. Nome (Red.), Det nye norskfaget (s. 161-188). Fagbokforlaget/LNU.

Blikstad-Balas, M. (2016). Literacy $i$ skolen. Universitetsforlaget.

Blikstad-Balas, M. (2018). Skrivediskurser i norskfaget - en analyse av hvordan norsklærere snakker om skriving på åttende trinn. Nordic Fournal of Literacy Research, 4(1). https://doi.org/10.23865/njlr.v4.1020

Carter, M., Ferzli, M. \& Wiebe, E. N. (2007). Writing to learn by learning to write in the disciplines. Fournal of business and Technical Communication, 21(3), 278-302. https://doi.org/10.1177/1050651907300466

Cope, B. \& Kalantzis, M. (1993). Introduction: how a genre approach to literacy can transform the way writing is taught. I B. Cope \& M. Kalantzis (Red.), The powers of literacy: A genre approach to teaching writing (s. 1-21). University of Pittsburg Press.

Dysthe, O., Hertzberg, F. \& Hoel, T. L. (2000). A skrive for å lare. Skriving i høyere utdanning. Abstrakt forlag.

Elstad, E. \& Turmo, A. (2006). Leringsstrategier og selvregulert laring. Universitetsforlaget.

Fang, Z. (2012). Language correlates of disciplinary literacy. Topics in language disorders, 32(1), 19-34. https://doi.org/10.1097/TLD.0b013e31824501de

Fang, Z. \& Coatoam, S. (2013). Disciplinary literacy: What you want to know about it. Fournal of Adolescent $\mathcal{E}$ Adult Literacy, 56(8), 627-632. https://doi.org/10.1002/JAAL. 190

Fairclough, N. (2003). Analysing discourse: textual analysis for social research. Routledge.

Fairclough, N. (2015). Language and power. (3. utg.). Routledge.

Flyum, K. H. (2011). Forberedende øvelser i skisseskriving, kildebruk og drøfting - en verktøymakers verktøy til fagskriving. I K. H. Flyum \& F. Hertzberg (Red.) Skriv $i$ alle fag! Argumentasjon og kildebruk $i$ videregående skole (s. 33-75). Universitetsforlaget.

Gjerustad, C., Waagene E. \& Federici, R. A. (2017). Spørsmål til Skole-Norge høsten 2016. Hentet fra https://www. udir.no/tall-og-forskning/finn-forskning/rapporter/sporsmal-til-skole-norge-hosten-2016/

Heath, S. B. (1983). Ways with words. Cambridge University Press.

Hoem, T., Håland, A. \& Skartveit, B. (2015). Kva vil det seie å vere leselærar på faget sine eigne premissar? Norsklceraren, 2/2015.

Knain, E. (2005a). Skriving i naturfag: mellom tekst og natur. Nordic Studies in Science Education, 1(1), 70-80. https://doi.org/10.5617/nordina.467

Knain, E. (2005b). Skriving omkring praktisk arbeid i naturfag. I R. T. Lorentzen \& J. Smidt (Red.), A skrive $i$ alle fag (s. 215-227). Universitetsforlaget.

Kvithyld, T. (2019). Hva skjer når lærere benytter pedagogiske ressurser anbefalt av utdanningsmyndighetene? Nordic Fournal of Literacy Research, 5(1). https://doi.org/10.23865/njlr.v5.1431

Lemke, J. L. (2004). The literacies of science. I E. W. Saul (Red.), Crossing borders in literacy and science instruction: Perspectives on theory and practice (s. 33-47). International Reading Association.

Lorentzen, R. T. \& Smidt, J. (Red.). (2008). A skrive $i$ alle fag. Universitetsforlaget.

Lykknes A. \& Arnesen, T. (2008). Fra lister til tankekart: skriving i naturfag i noen nye lærebøker. I R. T. Lorentzen \& J. Smidt (Red.), A skrive $i$ alle fag (s. 191-203). Universitetsforlaget.

Lykknes, A. \& Smidt, J. (2008). «Strukturert og ordentlig» - om å skrive forsøksrapport i naturfag på ungdomstrinnet. I R. T. Lorentzen \& J. Smidt (Red.), A skrive $i$ alle fag (s. 204-214). Universitetsforlaget.

Lykknes, A. (2015). A beskrive og utforske naturen. Naturfagrelevante skriveoppgaver i Normprosjektet. I H. Otnes (Red.), A invitere elever til skriving. Ulike perspektiver på skriveoppgaver (s. 159-180).

Matre, S., Solheim, R. \& Otnes, H. (2021). Nye grep om skriveopplceringa. Forskingsfunn og praksiserfaringar. Universitetsforlaget. 


\section{Skriving i naturfag}

Martin, J. R., Christie, F. \& Rothery, J. (1987). Social processes in education: a reply to Sawyer and Watson (et al.). I I. Reid (Red.), The place of genre in learning: current debates (s. 58-82). Dekain University, Centre for Studies in Literacy Education.

Meld. St. 30 (2003-2004). Kultur for lcering. Utdannings- og forskningsdepartementet.

Meld.St. 28 (2015-2016). Fag-Fordypning-Forståelse. En fornyelse av Kunnskapsløftet. Kunnskapsdepartementet.

Moje, E. B. (2010). Response: Heller's «In praise of amateurism: A friendly critique of Moje's 'call for change' in secondary literacy». Fournal of Adolescent $\mathcal{E}$ Adult Literacy, 54(4), 275-278. https://doi.org/10.1598/ JAAL.54.4.5

Moslet, I. (2009). Norsklærer. I I. Moslet (Red.), Norskdidaktikk - ei grunnbok (3. utg.). Universitetsforlaget.

Møller, J., Ottesen, E., \& Hertzberg, F. (2010). Møtet mellom skolens profesjonsforståelse og Kunnskapsløftet som styringsreform. Acta Didactica Norge, 4(1), Art.15. https://doi.org/10.5617/adno.1055

Maagerø, E. \& Skjelbred, D. (2010). De mangfoldige realfagstekstene. Fagbokforlaget.

NOU 2014: 7. (2014). Elevenes lering $i$ fremtidens skole. Kunnskapsdepartementet.

NOU 2015: 8. (2015). Fremtidens skole. Kunnskapsdepartementet.

Peterson, S. S., Parr, J., Lindgren, E. \& Kaufman, D. (2018). Conceptualizations of writing in early years curricula and standards documents: International perspectives. The Curriculum fournal, 29(4), 499-521. https://doi.org/10.1080/09585176.2018.1500489

Roe, A. \& Helstad, K. (2014). Den andre skriveopplæringen i Norge - om prosesskriving og skriving i og på tvers av fag. I R. Hvistendahl \& A. Roe (Red.), Alle tiders norskdidaktiker. Festtidsskrift til Frøydis Hertzberg på 70-årsdagen (s. 171-191). Novus Forlag.

Russell, D. R. (2002). Writing in the academic disciplines: a curricular history (2. utg.). Southern Illinois UP.

Rødnes, K. A. \& Gilje, Ø. (2018). Ti år med grunnleggende ferdigheter - hva vet vi, og hvor går vi? Norsk pedagogisk tidsskrift, 102(03), 201-213. https://doi.org/10.18261/issn.1504-2987-2018-03-02

Santa, C. \& Engen, L. (1996). Lere å lere (norsk utgave). Stiftelsen dysleksiforskning.

Shanahan, T. \& Shanahan, C. (2008). Teaching disciplinary literacy to adolescents: rethinking content area literacy. Harvard Educational Review, 78(1), 40-61.https://doi.org/10.17763/haer.78.1.v62444321 p602101

Shanahan, T. \& Shanahan, C. (2012). What is disciplinary literacy and why does it matter? Topics in Language Disorders, 32(1), 7-18. https://doi.org/10.1097/TLD.0b013e318244557a

Skaftun, A., Solheim, O. J. \& Uppstad, P. H. (Red.). (2014). Leseboka. Leseopplering $i$ alle fag på ungdomstrinnet. Cappelen Damm Akademisk.

Skjelbred, D. \& Aamotsbakken, B. (Red.). (2010). Lesing av fagtekster som grunnleggende ferdighet $i$ fagene (Bd. $1 \&$ 2). Novus.

Skjelbred, D. \& Veum, A. (Red.). (2013). Literacy i lceringskontekster. Cappelen Damm Akademisk.

Smidt, J. (Red.). (2011). Skriving $i$ alle fag - innsyn og utspill. Tapir akademisk forlag.

Street, B. (1984). Literacy in theory and practice. Cambridge University Press.

Sørvik, G. O. \& Mork, S. M. (2015). Scientific literacy as social practice: implications for reading and writing in science classrooms. NorDiNa, 11(3), 268-281. https://doi.org/10.5617/nordina.987

Sørvik, G. O., Blikstad-Balas, M. \& Ødegaard, M. (2015). «Do books like these have authors?» New roles for text and new demands on students in integrated science-literacy instruction. Science Education, 99(1), 39-69. https://doi.org/10.1002/sce. 21143

Torvatn, A. C. (2008). Avskrift, mønstre og forbilder i skriveundervisningen. I R. T. Lorentzen \& J. Smidt (Red.), A skrive $i$ alle fag (s. 147-158). Universitetsforlaget.

Utdanningsdirektoratet. (2006/2013). Lareplanverket for Kunnskapsløftet. Hentet fra http://www.udir.no/laringog-trivsel/lareplanverket/

Utdanningsdirektoratet. (2012/2017). Rammeverk for grunnleggende ferdigheter. Hentet fra https:/www.udir. no/laring-og-trivsel/lareplanverket/grunnleggende-ferdigheter/rammeverk-for-grunnleggende-ferdigheter/

Utdanningsdirektoratet. (2017). Ressurssider for Ungdomstrinn i utvikling. Hentet fra https://www.udir.no/laringog-trivsel/lareplanverket/grunnleggende-ferdigheter/skriving/\#98468

Utdanningsdirektoratet. (2017). Overordnet del - verdier og prinsipper. Hentet fra https://www.udir.no/lk20/ overordnet-del/

Utdanningsdirektoratet (2019). Lereplanverket for Kunnskapsløftet (LK20). Hentet fra: https://www.udir.no/ lk20/lareplanverket/

Veum, A. \& Skovholt, K. (2020). Kritisk literacy i klasserommet. Universitetsforlaget. 


\section{Lorentzen, M. -A. Igland og R. Solheim}

\section{Vedlegg}

Vedlegg 1. Hovedtrekk i inngangstekstene - komprimert oversikt. Basert på Faircloughs rammeverk for diskursanalyse i Analyzing Discourse (2003) og Language E Power, 3. utg. (2015).

\begin{tabular}{|c|c|c|c|c|}
\hline \multirow{3}{*}{$\begin{array}{l}\text { Fokus } \\
\text { Beskrivelse }\end{array}$} & \multicolumn{2}{|c|}{ Naturfagsenteret (inngangstekst A og B) } & \multicolumn{2}{|c|}{ Skrivesenteret (inngangstekst C og D) } \\
\hline & $\begin{array}{l}\text { A: Naturfag, lær- } \\
\text { ingsstrategier og } \\
\text { grunnleggende fer- } \\
\text { digheter ( } 2426 \text { ord) }\end{array}$ & $\begin{array}{l}\text { B: Lese, skrive og } \\
\text { samtale om natur- } \\
\text { vitenskapelige emner } \\
\text { (1614 ord) }\end{array}$ & $\begin{array}{l}\text { C: Skriving i realfag } \\
\text { ( } 692 \text { ord) }\end{array}$ & $\begin{array}{l}\text { D: Skriving i naturfag } \\
\text { (334 ord) }\end{array}$ \\
\hline & $\begin{array}{l}\text { Fagartikkel. Steg-for- } \\
\text { steg undervisnings- } \\
\text { opplegg. Krever flere } \\
\text { skroll. } 5 \text { s. i utskrifts- } \\
\text { vennlig format. }\end{array}$ & $\begin{array}{l}\text { Fagartikkel. Krever } \\
\text { flere skroll. } 4 \text { s. i ut- } \\
\text { skriftsvennlig format. }\end{array}$ & $\begin{array}{l}\text { Fagartikkel. Tradi- } \\
\text { sjonell (papirbasert) } \\
\text { oppbygning, tilpasset } \\
\text { mindre leseflate. } \\
\text { Krever få skroll. Vis- } \\
\text { er til utfyllende art., } \\
\text { publ. i ped. tidsskrift. }\end{array}$ & $\begin{array}{l}\text { Fagartikkel, tilpasset } \\
\text { nettformatet. Krever } \\
\text { få skroll. Inkluderer } \\
\text { instruksjonsvideo } \\
\text { med steg-for-steg un- } \\
\text { dervisningsopplegg. }\end{array}$ \\
\hline \multicolumn{5}{|l|}{ Språkbruk } \\
\hline $\begin{array}{l}\text { Ordvalg, } \\
\text { særlig } \\
\text { 1) gjentakel- } \\
\text { ser og } \\
\text { 2) synonymer }\end{array}$ & $\begin{array}{l}\text { 1) «eleven», "lær- } \\
\text { ingsstrategier», «stra- } \\
\text { tegi», «naturfag», } \\
\text { «lærer», "redskaper». } \\
\text { 2) «Redskap» og } \\
\text { «verktøy» ofte brukt } \\
\text { synonymt med } \\
\text { strategier. }\end{array}$ & $\begin{array}{l}\text { 1) «sjanger» (x 24), } \\
\text { ofte i kombinasjon } \\
\text { med «naturviten- } \\
\text { skapelig». } \\
\text { Deretter er "eleven», } \\
\text { «vurdere» og "kritisk» } \\
\text { de mest frekvente } \\
\text { ordene }\end{array}$ & $\begin{array}{l}\text { 1) «eleven», «skriv- } \\
\text { ing», «naturfag/-fag- } \\
\text { lig», «lære», «fag-ene», } \\
\text { sammensatte ord med } \\
\text { «språk» og "fag» } \\
\text { i første/siste ledd. } \\
\text { 2) for meningsskap- } \\
\text { ende ressurser }\end{array}$ & $\begin{array}{l}\text { 1) Ulike former av } \\
\text { «skriving», «eleven», } \\
\text { «naturfag/-faglig», } \\
\text { «tekst» og "skrive-- } \\
\text { prosess» er mest } \\
\text { frekvente. }\end{array}$ \\
\hline \multicolumn{5}{|l|}{ Sjanger } \\
\hline Nettverk & $\begin{array}{l}\text { Inngår i nettverk av sos } \\
\text { økt naturfaglig kompet }\end{array}$ & $\begin{array}{l}\text { ale praksiser som skal st } \\
\text { nse og interesse og skriv }\end{array}$ & $\begin{array}{l}\text { otte lærere og andre i ar } \\
\text { ing som grunnleggende }\end{array}$ & $\begin{array}{l}\text { rbeid med henholdsvis } \\
\text { ferdighet. }\end{array}$ \\
\hline $\begin{array}{l}\text { Sjanger- } \\
\text { beskrivelse }\end{array}$ & $\begin{array}{l}\text { Argumenterende fag- } \\
\text { art. om strategiopp- } \\
\text { læring for videreut- } \\
\text { vikling av naturfag- }\end{array}$ & $\begin{array}{l}\text { Primært informer- } \\
\text { ende tekst om natur- } \\
\text { vitenskapelige sjan- } \\
\text { gre og hvordan elever }\end{array}$ & $\begin{array}{l}\text { Argumenterende fag- } \\
\text { art. med PL-struktur. } \\
\text { Innslag av undervis- } \\
\text { ningsanbefalinger }\end{array}$ & $\begin{array}{l}\text { Skriftlig verbaltekst: } \\
\text { Informerende og ar- } \\
\text { gumenterende fagart. } \\
\text { tar til orde for at synl- }\end{array}$ \\
\hline $\begin{array}{l}\text { Sjanger- } \\
\text { blanding }\end{array}$ & $\begin{array}{l}\text { forståelse og grunn- } \\
\text { leggende ferdigheter. } \\
\text { Trekker på fagbok- } \\
\text { sjanger i beskrivelse } \\
\text { av og ref. til forskning } \\
\text { om læringsstra- } \\
\text { tegier og selvregulert } \\
\text { læring. Innslag av } \\
\text { lærerveiledning i be- } \\
\text { skrivelse av lærings- og } \\
\text { skrivestrategier. }\end{array}$ & $\begin{array}{l}\text { kan få trening i faglig } \\
\text { deltakelse gjennom å } \\
\text { lese, skrive og samtale } \\
\text { om tekster i slike } \\
\text { sjangre. }\end{array}$ & $\begin{array}{l}\text { som skal overbevise } \\
\text { lærere om at skrive- } \\
\text { opplæring på realfag- } \\
\text { enes premisser } \\
\text { utvikler elevenes } \\
\text { fagkunnskap. Trekker } \\
\text { på fagboksjangeren i } \\
\text { beskrivelse av tenke- } \\
\text { skriving (WAC) og } \\
\text { presentasjonsskriving } \\
\text { (WID). }\end{array}$ & $\begin{array}{l}\text { ig, eksplisitt under- } \\
\text { visning i fagspråk } \\
\text { og -sjangre fremmer } \\
\text { utvikling og læring. } \\
\text { Video: Lærerveiled- } \\
\text { ning som steg-for-steg } \\
\text { og med elevtekst som } \\
\text { eksempel modellerer } \\
\text { samtale om særtrekk } \\
\text { ved naturviten- } \\
\text { skapelig skrivemåte. }\end{array}$ \\
\hline
\end{tabular}




\section{Skriving $i$ naturfag}

\begin{tabular}{|c|c|c|c|c|}
\hline \multirow{2}{*}{$\begin{array}{l}\text { Fokus } \\
\text { Forpliktelser }\end{array}$} & \multicolumn{2}{|c|}{ Naturfagsenteret (inngangstekst A og B) } & \multicolumn{2}{|c|}{ Skrivesenteret (inngangstekst C og D) } \\
\hline & & & & \\
\hline $\begin{array}{l}\text { Stil (ways of } \\
\text { being) }\end{array}$ & $\begin{array}{l}\text { Opptrer som kjenner } \\
\text { av feltet grunnlegg- } \\
\text { ende ferdigheter og } \\
\text { læringsstrategier, og } \\
\text { som rådgivende in- } \\
\text { stans på området. }\end{array}$ & $\begin{array}{l}\text { Opptrer som kjenner } \\
\text { av arbeid med grunn- } \\
\text { leggende ferdigheter } \\
\text { i naturvitenskapelige } \\
\text { emner i skolen (forf. } \\
\text { er universitetsansatt). } \\
\text { Inntar rolle som råd- } \\
\text { giver for skolens ar- } \\
\text { beid med grunnlegg- } \\
\text { ende ferdigheter i } \\
\text { naturfag. }\end{array}$ & $\begin{array}{l}\text { Instruerende ramme- } \\
\text { tekst innleder og } \\
\text { avrunder utdrag fra } \\
\text { lærebok for høyere } \\
\text { utdanning. Kombi- } \\
\text { nerer instruksjon om } \\
\text { skriveopplæring med } \\
\text { informasjon om skri- } \\
\text { veteori. Opptrer som } \\
\text { kjenner og formidler } \\
\text { av skriveforskning. }\end{array}$ & $\begin{array}{l}\text { Opptrer som kjenner } \\
\text { av naturvitenskapens } \\
\text { språklige egenart. } \\
\text { Veiledende stil, rettet } \\
\text { først og fremst mot } \\
\text { lærere. }\end{array}$ \\
\hline Modalitet & $\begin{array}{l}\text { Kan/kunne: } 42 \\
\text { Må: } 5 \\
\text { Skal: } 8 \\
\text { Bør/burde: } 0 \\
\text { EKS: } \\
\text { «Det kan bidra til, } \\
\text { læreren må vise } \\
\text { elevene, skolen og } \\
\text { lærebedriften skal } \\
\text { stimulere elevene og } \\
\text { lærlingene/lærekandi- } \\
\text { datene» }\end{array}$ & $\begin{array}{l}\text { Kan/kunne } 24 . \text { Må } 4 . \\
\text { Skal 13. Bør/burde } 4 . \\
\text { EKS: «kan være viktig, } \\
\text { kritisk vurdering kan } \\
\text { minke avstanden, } \\
\text { vil kunne gjøre dem } \\
\text { trygge, kan diskuteres, } \\
\text { elevene kan lære. } \\
\text { «Vi må søke å trene } \\
\text { elevene, elevene må } \\
\text { forstå teorien/må } \\
\text { trene på anvendelse.» } \\
\text { Skal er med ett unn- } \\
\text { tak knyttet til det } \\
\text { elevene skal mestre. }\end{array}$ & $\begin{array}{l}\text { Kan/kunne: } 4 \\
\text { Må: } 9 \\
\text { Skal: } 4 \\
\text { Bør/burde: } 0 \\
\text { EKS: } \\
\text { «Det vi kan kalle, } \\
\text { elevene må, læreren } \\
\text { må, elevene skal } \\
\text { kunne» } \\
\text { Hovedsakelig deontisk } \\
\text { modalitet. }\end{array}$ & $\begin{array}{l}\text { Kan/kunne:3 } \\
\text { Må: } 0 \\
\text { Skal: } 0 \\
\text { Bør/burde: } 0 \\
\text { EKS: } \\
\text { «Hvordan kan man } \\
\text { legge til rette for, } \\
\text { hvordan de selv kan } \\
\text { konstruere, elevenes } \\
\text { egne tekster kan med } \\
\text { fordel» }\end{array}$ \\
\hline $\begin{array}{l}\text { Represen- } \\
\text { tasjon av } \\
\text { sosiale } \\
\text { hendelser: } \\
\text { pronomen } \\
\text { agens } \\
\text { metaforer }\end{array}$ & $\begin{array}{l}\text { Forfatteren er tydelig } \\
\text { til stede med klare an- } \\
\text { befalinger for lærerens } \\
\text { handlinger. } \\
\text { Inkluderende «vi» brukt } \\
\text { når forfatter og leser/ } \\
\text { lærer jamstilles. } \\
\text { «Du» er ikke brukt. } \\
\text { Mange metaforer: } \\
\text { «I vinden»: lærings- } \\
\text { begreper med dags- } \\
\text { aktuell relevans. }\end{array}$ & $\begin{array}{l}\text { Kollektivt «vi» } \\
\text { gjennomgående brukt } \\
\text { om fagfolk og lærere. } \\
\text { «De» om elevene. } \\
\text { Bidrar til ubestridelig } \\
\text { common sense, } \\
\text { fagfolk og lærere er } \\
\text { omforent om hva } \\
\text { som er best for dem } \\
\text { (elevene). }\end{array}$ & $\begin{array}{l}\text { «Vi» om den/de som } \\
\text { står bak teksten: «Vi } \\
\text { vil hevde at», "På } \\
\text { denne siden viser vi». } \\
\text { Kollektivt «vi» om } \\
\text { skriver og leser brukt } \\
\text { én gang for å gi } \\
\text { inntrykk av at skriver } \\
\text { og leser er omforent } \\
\text { om det som sies: «det } \\
\text { vi kan kalle for». } \\
\text { «Du» brukt én gang } \\
\text { for å adressere leser- } \\
\text { en (læreren) direkte: } \\
\text { «til høyre finner du } \\
\text { ressurser om». }\end{array}$ & $\begin{array}{l}\text { «Vi» og "du» er ikke } \\
\text { brukt. Prosesser, } \\
\text { skriving og under- } \\
\text { visning i forgrunnen. } \\
\text { «Læreren» og "elev- } \\
\text { ene» er også aktører. } \\
\text { Mange nominaliser- } \\
\text { inger: skriving, } \\
\text { undervisning. Agens } \\
\text { ofte nedtonet eller } \\
\text { innforståt, f.eks. i } \\
\text { beskrivelser av god } \\
\text { skriving i naturfag } \\
\text { hvor det er under- } \\
\text { forstått at den gode } \\
\text { skriveren innehar } \\
\text { disse ferdighetene. }\end{array}$ \\
\hline
\end{tabular}


Vedlegg 1. (Forts.)

\begin{tabular}{|c|c|c|c|c|}
\hline Fokus & \multicolumn{2}{|c|}{ Naturfagsenteret (inngangstekst A og B) } & \multicolumn{2}{|c|}{ Skrivesenteret (inngangstekst C og D) } \\
\hline & $\begin{array}{l}\text { «Redskaper» og } \\
\text { «verktøy» om strate- } \\
\text { gier, jamfører hånd- } \\
\text { verkerens redskaps- } \\
\text { behov med elevens } \\
\text { behov for strategier. } \\
\text { Krigs-/kampmeta- } \\
\text { forer: } \\
\text { - «Angripe tekstene» } \\
\text { om lesing. } \\
\text { - «Strategi» i seg } \\
\text { selv og sammen } \\
\text { med «målrettet». } \\
\text { «Modellere» om } \\
\text { mesteren som viser } \\
\text { literacy-kunsten. } \\
\text { «Nøkkelprinsipp» } \\
\text { (for strategiundervis- } \\
\text { ning), om prinsipper } \\
\text { som åpner for god } \\
\text { strategiundervisning. }\end{array}$ & $\begin{array}{l}\text { «Vi» kan også inklu- } \\
\text { dere andre: i «et } \\
\text { prosjekt knyttet til Rå } \\
\text { ungdomsskole uten- } \\
\text { for Bergen arbeider vi } \\
\text { sammen med Statoil» } \\
\text { «Jeg» er brukt to ste- } \\
\text { der: «Elevenes rap- } \\
\text { porter vil jeg for ek- } \\
\text { sempel ofte vurdere } \\
\text { til å være en blanding } \\
\text { av» og «Med auten- } \\
\text { tiske tekster tenker } \\
\text { jeg på». } \\
\text { «Du» er også brukt en } \\
\text { gang ifm råd til lærer } \\
\text { om spm. man kan } \\
\text { stille til eleven. }\end{array}$ & $\begin{array}{l}\text { Agens skifter mellom } \\
\text { - tekstprodusenten, } \\
\text { - nominaliserte pro- } \\
\text { sesser (språkarbeid), } \\
\text { - læreren (instruks } \\
\text { om spesifikke } \\
\text { handlinger i } \\
\text { klasserommet, } \\
\text { - elevene (i beskrivel- } \\
\text { ser av hva de må } \\
\text { gjøre for å bli gode } \\
\text { skrivere i faget) } \\
\text { - lærebøker, lærerut- } \\
\text { danning (samt tradi- } \\
\text { sjon har unnlatt be- } \\
\text { visstgjøring om fags } \\
\text { språklige egenart. }\end{array}$ & $\begin{array}{l}\text { Ressursen har lærere } \\
\text { som målgruppe, men } \\
\text { agens erogså utelatt } \\
\text { eller nedtonet der det } \\
\text { kunne vært relevant } \\
\text { å adressere læreren } \\
\text { direkte. Teksten } \\
\text { framstår som mindre } \\
\text { normativ. Hva eleven } \\
\text { bør gjøre i godt til- } \\
\text { rettelagt undervis- } \\
\text { ning adresseres, gir } \\
\text { samtidig beskrivelse } \\
\text { av hva den gode } \\
\text { læreren bør gjøre. }\end{array}$ \\
\hline \multicolumn{5}{|c|}{ Fortolkninger } \\
\hline $\begin{array}{l}\text { Ordsam- } \\
\text { menstill- } \\
\text { inger } \\
\text { Antakelser }\end{array}$ & $\begin{array}{l}\text { Strategidiskurs } \\
\text { for-ankret i } \\
\text { ferdighetsbasert } \\
\text { literacy-ideologisk } \\
\text { ståsted, legitimeres } \\
\text { og promoteres } \\
\text { gjennom gjentatte } \\
\text { koplinger mellom } \\
\text { læringsstrategier og } \\
\text { grunnleggende fer- } \\
\text { digheter/skrivekompe } \\
\text {-tanse/intuitiv for- } \\
\text { ståelse/leseforståelse/ } \\
\text { effektiv læring/ } \\
\text { eksperter på læring/ } \\
\text { faglige prestasjoner/ } \\
\text { strategisk tenking og } \\
\text { beskrivelsen «naturlig». }\end{array}$ & $\begin{array}{l}\text { Skal elevene bli full- } \\
\text { verdige deltakere i } \\
\text { et demokratisk sam- } \\
\text { funn, må de kunne } \\
\text { forholde seg åpent og } \\
\text { kritisk vurderende til } \\
\text { (naturfaglige) tekster } \\
\text { som inngår i ulike } \\
\text { sammenhenger. } \\
\text { Et allmenndannende } \\
\text { naturfag fremmer } \\
\text { evne til deltakelse. } \\
\text { Faglige arbeids-, opp- } \\
\text { gave- og prøveformer } \\
\text { fremmer forsknings- } \\
\text { interesse og -forstå- } \\
\text { else, samt deltakelse } \\
\text { i diskusjoner om på- } \\
\text { standers pålitelighet. }\end{array}$ & $\begin{array}{l}\text { Tradisjonell skrive- } \\
\text { oppl.: (real-)faglærere } \\
\text { er ikke skrivelærere. } \\
\text { Tradisjon, lærer- } \\
\text { utdanning og lære- } \\
\text { bøker tillegges ansvar } \\
\text { for villedning av lær- } \\
\text { ere pga manglende } \\
\text { språkbasert skrive- } \\
\text { fokus. Språkarbeid } \\
\text { framholdt som forut- } \\
\text { setning for utvikling } \\
\text { av fagkunnskap og } \\
\text { vice versa. Språkba- } \\
\text { sert ideologi (WAC/ } \\
\text { WID/DL). Antakelser } \\
\text { assosiert med skole- } \\
\text { politisk literacy-dis- } \\
\text { kurs: grunnleggende } \\
\text { ferdigheter som forut- } \\
\text { setning for læring og } \\
\text { deltakelse i et kunn- } \\
\text { skapsdrevet (skrift-) } \\
\text { samfunn. }\end{array}$ & $\begin{array}{l}\text { Skriving utvikler } \\
\text { kunnskap i fag. } \\
\text { Læring fremmes } \\
\text { gjennom eksplisitt } \\
\text { undervisning i fagets } \\
\text { språk og sjangre. } \\
\text { (Merk også sammen- } \\
\text { koblingen «skriving } \\
\text { er en nødvendig for- } \\
\text { utsetning for å»). } \\
\text { Antakelser assosiert } \\
\text { med samme } \\
\text { skolepolitiske literacy- } \\
\text { diskurs (ideologiske } \\
\text { prosjekt) som ressurs } \\
\text { C. }\end{array}$ \\
\hline
\end{tabular}




\section{Skriving $i$ naturfag}

\begin{tabular}{|c|c|c|c|c|}
\hline \multirow{2}{*}{$\begin{array}{l}\text { Fokus } \\
\text { Forankringer }\end{array}$} & \multicolumn{2}{|c|}{ Naturfagsenteret (inngangstekst A og B) } & \multicolumn{2}{|c|}{ Skrivesenteret (inngangstekst C og D) } \\
\hline & & & & \\
\hline $\begin{array}{l}\text { Intertekst- } \\
\text { ualitet } \\
\text { (manifest og } \\
\text { latent) }\end{array}$ & $\begin{array}{l}\text { Sitert med referanser: } \\
\text { LK06, Læringspla- } \\
\text { katen, St. meld. 30, } \\
\text { bøker om lærings- og } \\
\text { lesestrategier (Engen, } \\
\text { 1998, 2003; Santa \& } \\
\text { Engen, 1996) og bok } \\
\text { om PISA-resultater } \\
\text { (Kjærnslie et al., } \\
\text { 2004). }\end{array}$ & $\begin{array}{l}\text { LK06 er sitert i } \\
\text { teksten. Forfatterens } \\
\text { egen forskning på } \\
\text { feltet er vist til uten } \\
\text { eksplisitte referanser. }\end{array}$ & $\begin{array}{l}\text { Referanser til LK06 } \\
\text { og bok om skriving } \\
\text { for å lære (Hertzberg } \\
\text { \& Hoel, 2000). }\end{array}$ & $\begin{array}{l}\text { Referanser til } \\
\text { beskrivelsen av } \\
\text { skriving i naturfag i } \\
\text { LK06. } \\
\text { Henvisning til elev- } \\
\text { enes muligheter for } \\
\text { utvikling og lcering } \\
\text { gjenkjennes fra be- } \\
\text { skrivelser av literacy- } \\
\text { begrepet. }\end{array}$ \\
\hline \multirow[t]{2}{*}{ Diskurser } & $\begin{array}{l}\text { Læringsstrategi- } \\
\text { diskurs, kreativitet- } \\
\text { diskurs, norskfag- } \\
\text { diskurs (skriving i } \\
\text { norskfaglige sjangre). } \\
\text { Strategi-diskursen } \\
\text { posisjoneres som } \\
\text { autoritativ, tar til orde } \\
\text { for ferdighetsbasert } \\
\text { tilnærming til literacy- } \\
\text { utvikling }\end{array}$ & $\begin{array}{l}\text { Sjangerdiskurs. } \\
\text { Kritisk literacy- } \\
\text { diskurs }\end{array}$ & $\begin{array}{l}\text { Skrivedidaktisk } \\
\text { diskurs posisjonert } \\
\text { som autoritativ. } \\
\text { Sjangerdiskurs. }\end{array}$ & $\begin{array}{l}\text { Bærer oppe australsk } \\
\text { sjangerpedagogisk } \\
\text { diskurs med sterk } \\
\text { vektlegging av språk- } \\
\text { og tekstanalyse uten } \\
\text { at denne retningen er } \\
\text { eksplisitt nevnt. } \\
\text { Spor av skrivepeda- } \\
\text { gogisk prosess- } \\
\text { diskurs. }\end{array}$ \\
\hline & $\begin{array}{l}\text { Finner overlappende } \mathrm{d} \\
\text { diskurs med vekt på k } \\
\text { samfunnsmessig nytte. }\end{array}$ & $\begin{array}{l}\text { urser i alle inngangst } \\
\text { skaper og ferdigheter }\end{array}$ & $\begin{array}{l}\text { stene. Ser også spor a } \\
\text { or økonomisk verdisk }\end{array}$ & $\begin{array}{l}\text { en skolepolitisk } \\
\text { ping og }\end{array}$ \\
\hline
\end{tabular}

